\title{
Neogene benthic foraminifera from the southern Bering Sea (IODP Expedition 323)
}

\author{
Eiichi Setoyama and Michael A. Kaminski
}

\begin{abstract}
This study describes a total of 95 calcareous benthic foraminiferal taxa from the Pliocene-Pleistocene recovered from IODP Hole U1341B in the southern Bering Sea with illustrations produced with an optical microscope and SEM. The benthic foraminiferal assemblages are mostly dominated by calcareous taxa, and poorly diversified agglutinated forms are rare or often absent, comprising only minor components. Elongate, tapered, and/or flattened planispiral infaunal morphotypes are common or dominate the assemblages reflecting the persistent high-productivity and hypoxic conditions in the deep Bering Sea. Most of the species found in the cores are long-ranging, but we observe the extinction of several cylindrical forms that disappeared during the midPleistocene Climatic Transition.
\end{abstract}

Eiichi Setoyama. Earth Sciences Department, Research Group of Reservoir Characterization, King Fahd University of Petroleum \& Minerals, Dhahran, 31261, Saudi Arabia current address: Energy \& Geoscience Institute, University of Utah, 423 Wakara Way, Suite 300, Salt Lake City, Utah 84108, USA esetoyama@egi.utah.edu Michael A. Kaminski. Earth Sciences Department, Research Group of Reservoir Characterization, King Fahd University of Petroleum \& Minerals, Dhahran, 31261, Saudi Arabia kaminski@kfupm.edu.sa

Keywords: Bering Sea; biostratigraphy; foraminifera; palaeoceanography; Pliocene-Pleistocene; taxonomy Submission: 19 February 2014. Acceptance: 1 July 2015

\section{INTRODUCTION}

The Bering Sea is a large, permanently hypoxic deep basin that has a well-developed oxygen-minimum zone (Takahashi et al., 2011). Despite being one of the largest marginal seas, whose dimensions are comparable to that of the Mediterranean, the fossil benthic foraminiferal assemblages of the Bering Sea have barely been studied. Drilling in the southern Bering Sea during Integrated Ocean Drilling Program (IODP) Expedition 323 has provided the first opportunity to study the foraminiferal assemblages and palaeoceanographic proxies in continuously-cored sections in the deeper, southern part of the Bering Sea, with an aim toward assessing the effects of climate change on the benthic fauna.

Although benthic foraminifera have been studied from modern sea floor samples and from upper Quaternary sediments in short cores collected from the Bering Sea area (Anderson, 1963; Khusid et al., 2006), the only published record of the older Pleistocene and Neogene foraminiferal assem-

Setoyama, Eiichi and Kaminski, Michael A. 2015. Neogene benthic foraminifera from the southern Bering Sea (IODP Expedition 323). Palaeontologia Electronica 18.2.38A: 1-30 palaeo-electronica.org/content/2015/1264-bering-benthic-forams 


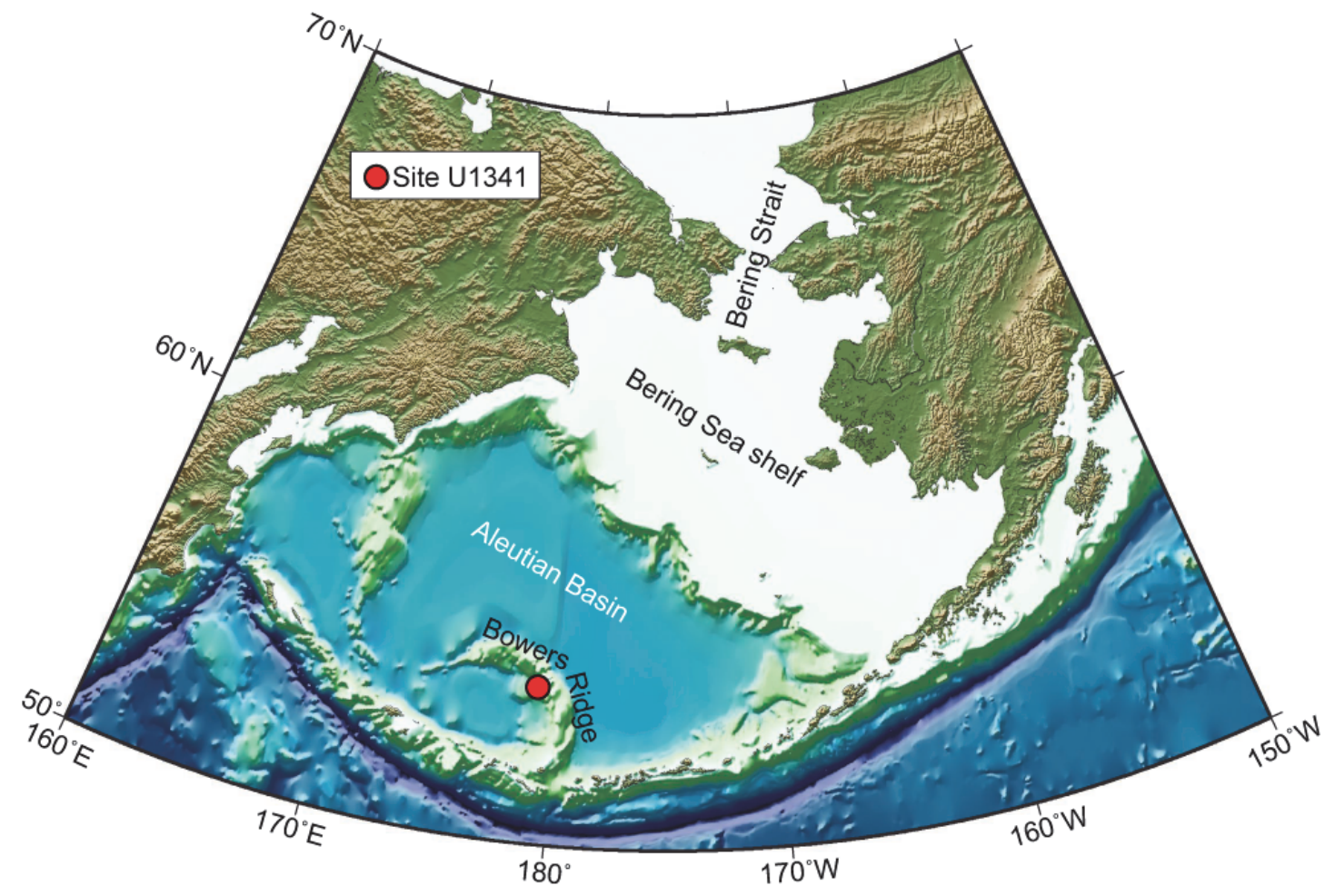

FIGURE 1. Location of Site U1341 in the Bering Sea. The map is adopted and modified from Expedition 323 scientists (2011).

blages of the Bering Sea remains that of Echols (1973) from Deep Sea Drilling Project Leg 19. Unfortunately, none of these reports provided adequate illustrations of the benthic foraminifera.

The purpose of this study is to provide a firmer taxonomic basis for further studies of the upper Neogene foraminifera in the Bering Sea and adjacent areas of the North Pacific. The agglutinated foraminifera from noncalcareous sediments in the deeper cored intervals of IODP Hole 1341B have been previously described by Kaminski et al. (2013). This study, therefore, focuses on the benthic foraminifera recovered from the stratigraphically younger intervals in Hole 1341B, some of which show excellent preservation of calcareous microfossils.

\section{GEOLOGICAL SETTING}

Site U1341 is located just below the modern dissolved oxygen-minimum zone in the Bering Sea. Hole U1341B was drilled at a water depth of $2139.5 \mathrm{~m}$ on the western flank of the central part of Bowers Ridge (Figure 1), and recovered $594.98 \mathrm{~m}$ of cores in total. The bottom of Hole U1341B is estimated between 4.1 and $5.0 \mathrm{Ma}$ (Onodera et al., 2013). Three lithological units were recognised, with Unit III subdivided into two subunits. Unit I is composed of alternating diatom ooze and mixed diatom-siliciclastic lithologies, and Unit II consisting of mostly diatom ooze with an interval dominated by mixed diatom-siliciclastic lithologies. Subunit IIIA is mainly olive silty clay with some authigenic carbonates, and Subunit IIIB includes diatom ooze, diatom silty clay, and authigenic carbonate in an interval between Cores U1341B-62X and -64X. Thin, distinct, parallel laminations are only recorded in intervals in Unit I, whereas thickly laminated to thinly bedded intervals are found in all units.

\section{MATERIALS AND METHODS}

Sediment samples, ca. 20cc, were collected during the postcruise sampling party from the interval between Cores U1341B-1H and -71X. The samples were gently disintegrated and washed over a $63-\mu \mathrm{m}$ sieve using only water. Foraminiferal specimens were picked and arranged in microslides after being air-dried. The number of specimens for each taxon is given in the Appendix. Optical microscope photographs were made using a Nikon digital camera Digital Sight DS-Fi 1 mounted on a Nikon-1500 stereomicroscope, and 
SEM images were taken with JEOL JSM-5900 SEM at the Earth Sciences Department, King Fahd University of Petroleum \& Minerals in Dhahran, Saudi Arabia. Optical microscopic photographs were processed using the focus stacking software CombineZP to combine images photographed at different depths of field to produce an image with a greater depth of field. Foraminiferal specimens are stored in faunal slides and deposited in the collections of Micropress Europe, AGH University of Science \& Technology, in Kraków, Poland.

\section{FORAMINIFERAL ASSEMBLAGES}

A total of 95 calcareous benthic taxa are recorded from the interval between Cores $1 \mathrm{H}$ and 71X in Hole 1341B. The benthic foraminiferal assemblages are wholly or mostly composed of calcareous forms, especially in the younger interval. Agglutinated foraminifera are often absent or comprise a very small portion. The impoverished agglutinated assemblages consisting mostly of Karreriella and Martinottiella in the upper half of the studied interval are taxonomically very similar to the assemblages described by Kaminski et al. (2013) from the lower portion of the cored section in Hole 1341B (see Expedition 323 Scientists, 2011). Throughout the studied interval, elongated, tapered, and/or flattened planispiral forms, such as Eubuliminella, Globobulimina, Melonis, and Uvigerina, which are, in general, infaunal and tolerant to oxygen-depleted conditions (see Corliss, 1985, 1991; Bernhard, 1986), are very common or dominate the Bering Sea assemblages. These forms are also reported to comprise a large portion of assemblages in high productivity areas (e.g., Fariduddin and Loubere, 1997; Koho et al., 2008; Caulle et al., 2014). The composition of the assemblages from the studied interval, thus, indicates prevailing high productivity and hypoxic conditions in the study area (see Figure 2). The assemblages from the interval between Cores $1 \mathrm{H}$ and $11 \mathrm{H}$, Assemblage I in Expedition 323 Scientists (2011), are relatively highly diversified and abundant. The specimens are well preserved in this interval. Eubuliminella exilis, Rutherfordoides tenuis, Islandiella helenae, Melonis affinis, and Uvigerina senticosa commonly occur, and several species including E. exilis, Globocassidulina neomargareta, Nonionella digitata, are confined to this interval. The interval between Cores $12 \mathrm{H}$ and $37 \mathrm{H}$ contains assemblages, which are generally less abundant, but similarly diversified to those from the top interval. Two samples from Core $36 \mathrm{H}$ are exceptional, and the assemblages contain more than 200 cal- careous benthic individuals. Hansenisca sp. A, I. helenae, $M$. affinis, Pullenia bulloides, and $U$. senticosa occur commonly in samples where foraminiferal specimens are present. These assemblages belong to Assemblage II in Expedition 323 Scientists (2011). The samples from Cores $38 \mathrm{H}-45 \mathrm{H}$ (Assemblage III in Expedition 323 Scientists, 2011) are barren of calcareous microfossils. Below the barren interval, low diversity and impoverished assemblages are observed in Cores $46 \mathrm{H}-71 \mathrm{X}$ (Assemblage $\mathrm{VI}$ in Expedition 323 Scientists, 2011), and many of the samples contain only agglutinated foraminifera (Kaminski et al., 2013). The preservation of the specimens is variable, and Hansenisca sp. A, Parrelloides healdi, Uvigerina proboscidea, and $U$. senticosa are occasionally recorded in this interval.

\section{BIOSTRATIGRAPHY}

There is a clear difference between the samples above Core $12 \mathrm{H}$ and those from deeper intervals of the core. The assemblages are more abundant and diversified, and the preservation state of the specimens is very good to excellent above Core $12 \mathrm{H}$. Some species, such as Takayanagia cf. Takayanagia cushmani, E. exilis, and $N$. digitata, are also confined to this younger interval. Cylindrical forms, including Epelistoma, Neugeborina, Siphonodosaria?, and Stilostomella, that belong to the group which went extinct during the Last Global Extinction in the late Pliocene-middle Pleistocene (Hayward et al., 2012) disappear at or below Sample 13H-5, 146-148 cm. This level may well represent the onset of the mid-Pleistocene Climate Transition (1.2-0.55 Ma) because the peak of the global extinction is recorded during the midPleistocene Climate Transition (Hayward et al., 2012). The proposed age of the interval between Samples $11 \mathrm{H}-\mathrm{CC}$ and $12 \mathrm{H}-3,144-146 \mathrm{~cm}$ is 0.9 1.0 Ma (Onodera et al., 2013) which falls within the time range of the climate transition. The first occurrences of some species, such as Alabaminella weddelensis, Brizalina pacifica and Fursenkoina complanata, are recorded in Sample $37 \mathrm{H}-3,148-$ $150 \mathrm{~cm}$, just above Assemblage III, which is mostly barren.

\section{SYSTEMATICS}

The suprageneric classification of this study is based on Loeblich and Tappan (1987) with modification following Pawlowski et al. (2013). The identification of species is primarily based on the monographs of McCulloch (1977) and Jones 


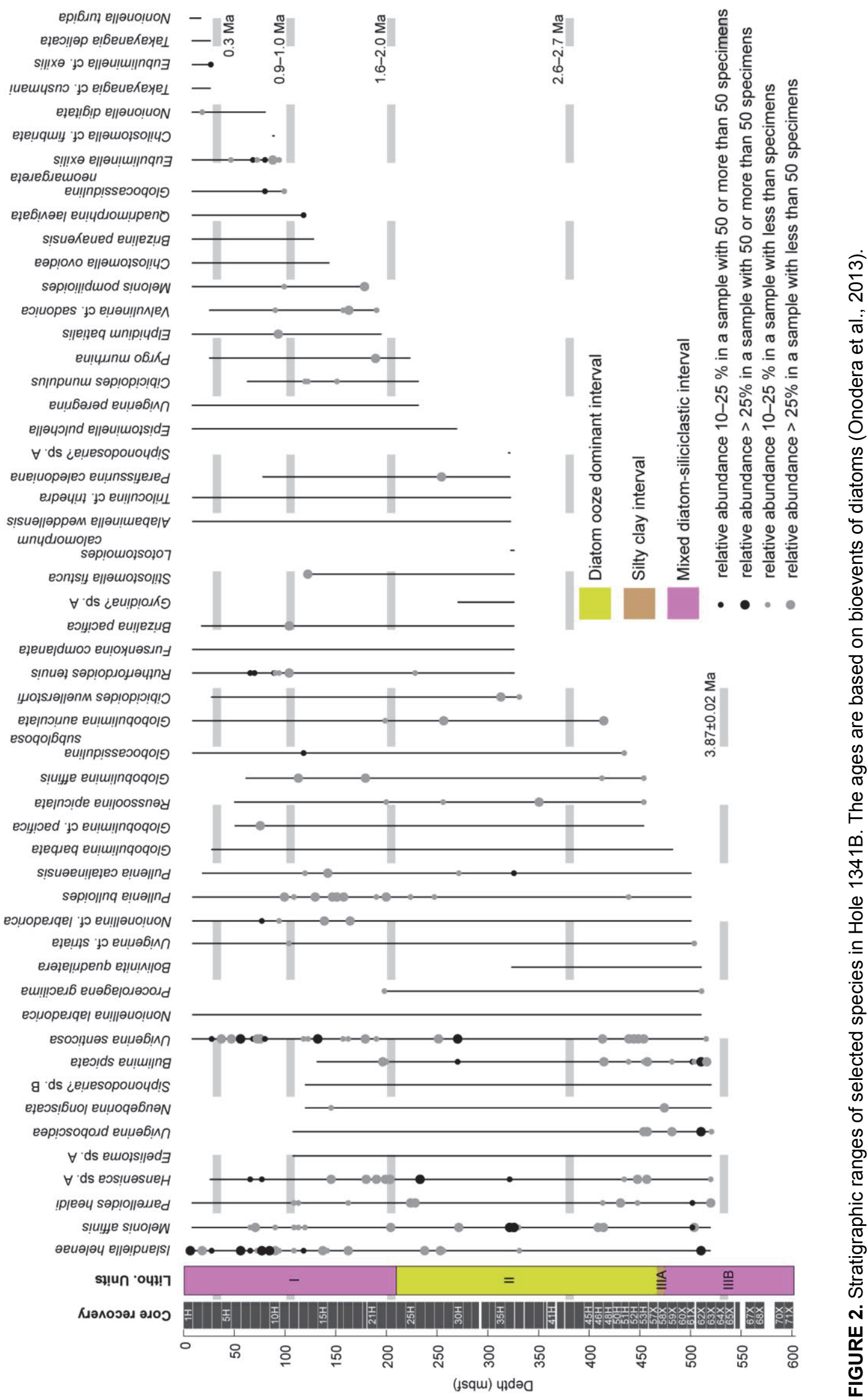


(1994). Additional literature on foraminifera from the eastern Pacific (e.g., Matoba and Yamaguchi, 1982; Hermelin, 1989), California (Finger, 1990, 1992), and areas around Japan (e.g., Matoba, 1967; Kaiho, 1992) were consulted. Identified taxa are illustrated in Figures 3-8.

Phylum FORAMINIFERA (d'Orbigny, 1826)

Class TUBOTHALAMEA Pawlowski, Holzmann and Tyszka, 2013

Order MILIOLIDA Delage and Hérouard, 1896

Family HAUERINIDAE Schwager, 1876

Subfamily MILIOLINELLINAE Vella, 1957

Genus PYRGO Defrance, 1824

Pyrgo murrhina (Schwager, 1866)

Figure $3.1 \mathrm{a}, \mathrm{b}$

1866 Biloculina murrhina Schwager: p. 203, pl. 4, fig. 15.

1884 Biloculina depressa var. murrhyna Schwager; Brady, p.146, pl. 2, figs. 10, 11.

1994 Pyrgo murrhina (Schwager); Jones, p. 18, pl. 2, figs. 10, 11, 15.

2013 Pyrgo murrhina (Schwager); Holbourn, Henderson and MacLeod, p. 458.

Remarks. Specimens greatly vary in size and shape as noted by Holbourn et al. (2013).

\section{Pyrgo sp. A \\ Figure 3.2a, b}

1989 Pyrgo sp. 1: Hermelin, p. 37, pl. 3, figs. 1, 2.

Description. Test small, biloculine, oval in outline, subcircular in cross section with inflated chambers and a keeled periphery. Aperture rounded, terminal on a prominent apertural neck with a tooth.

Remarks. The specimens resemble Pyrgo affinis (d'Orbigny, 1846), but differ by possessing a clear apertural neck and its smaller size. It is also similar to juvenile forms of Pyrgo nasutus Cushman (1935), but the periphery is not as strongly keeled and serrated. It may well be a juvenile of Pyrgo murrhina as suggested by Hermelin (1989).

Genus TRILOCULINA d'Orbigny, 1826

Triloculina cf. Triloculina trihedra Loeblich and Tappan, 1953

Figure 3.3a, b

1953 Triloculina trihedra Loeblich and Tappan: $p$. 45, pl. 4, fig. 10.

Remarks. The specimens are more elongate and slender than the specimens illustrated by Loeblich and Tappan (1953) and Cole and Ferguson (1975).

Class GLOBOTHALAMEA Pawlowski, Holzmann, and Tyszka, 2013
Order ROTALIIDA (Delage and Hérouard, 1896)

Superfamily BOLIVINACEA Glaessner, 1937

Family BOLIVINIDAE Glaessner, 1937

Genus BOLIVINA d'Orbigny, 1839b

Bolivina seminuda Cushman, 1911

Figure 3.4

1911 Bolivina seminuda Cushman: p. 34, fig. 55.

1982 Bolivina seminuda Cushman; Matoba and Yamaguchi, p. 1036, pl. 1, fig. 14a, b.

Remarks. The specimens resemble Bolivina seminuda forma $\mathrm{C}$ described by Matoba and Yamaguchi (1982), which is less tapered and possesses a more circular cross section than the other two forms ( $A$ and $B$ ) described from the PlioceneHolocene in the Gulf of California.

Bolivina sp. A

Figures 3.5a, 3.5b, 8.1

Description. Test small, elongated, tapered, biserial. Periphery slightly lobulated, bluntly angled. Chambers increasing in size gradually. Sutures depressed, sinuous, oblique. Wall rough. Aperture a basal, high arch.

\section{Bolivina spp.}

Remarks. Poorly preserved, small specimens are included.

Genus BRIZALINA Costa, 1856

Brizalina pacifica (Cushman and McCulloch, 1942)

Figures 3.6a, 3.6b, 8.2

1942 Bolivina acerosa Cushman var. pacifica Cushman and McCulloch: p. 185, pl. 21, figs. 2, 3.

1970 Bolivina pacifica (Cushman and McCulloch); Sliter, p. 168, pl. 7, fig. 5.

1981 Brizalina pacifica (Cushman and McCulloch); Finger and Lipps, p. 129, pl. 2, fig. 6.

2012 Brizalina pacifica (Cushman and McCulloch); Ishimura, p. 4364, figs. 2d, g, h, 3j.

Description. Test elongated, slender, oval in cross section with rounded periphery. Chambers increasing in size gradually. Sutures clear, very slightly depressed, oblique, slightly curved. Wall smooth, finely perforated. The upper part of each chamber is clear. Aperture a narrow loop at the base of the last chamber.

Remarks. It differs from Brizalina earlandi (Parr, 1950 ) by possessing more than twelve chambers of which the upper part is clear.

Brizalina panayensis McCulloch, 1977

Figures 3.7a, 3.7b, 8.3 


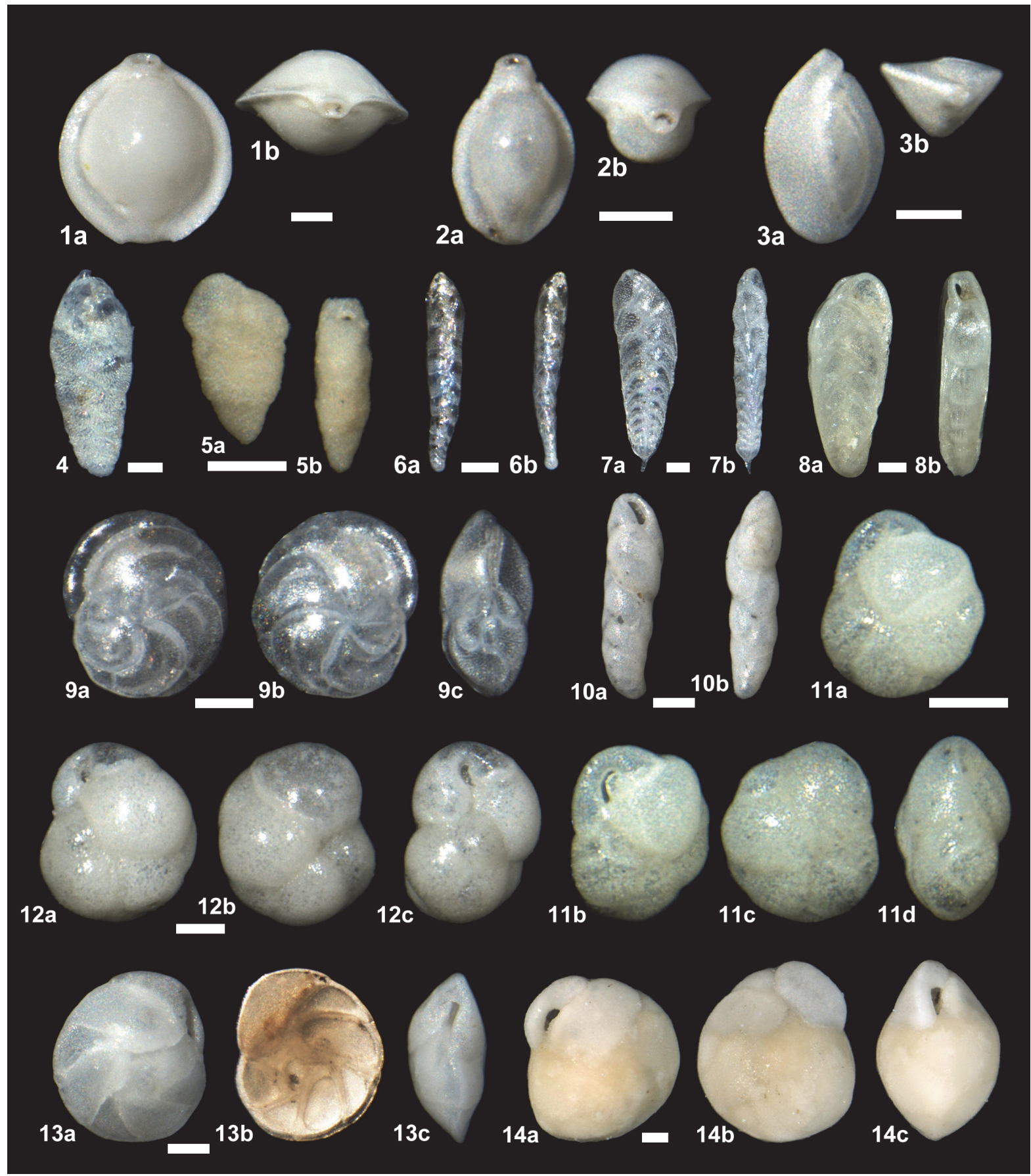

FIGURE 3. All scale bars are $100 \mu \mathrm{m}$. 1. Pyrgo murrhina, $13 \mathrm{H}-3,146-148 \mathrm{~cm}$; a. lateral view; b. apertural view. 2. Pyrgo sp. A, 13H-3, 146-148 cm; a. lateral view; b. apertural view. 3. Triloculina cf. Triloculina trihedra, 9H-5, 146$148 \mathrm{~cm}$; a. lateral view; b. apertural view. 4. Bolivina seminuda, 3H-CC, lateral view. 5. Bolivina sp. A, 36H-CC; a. lateral view; b. edge view showing the asymmetrically positioned aperture. 6 . Brizalina pacifica, $11 \mathrm{H}-5,146-148 \mathrm{~cm}$; $a$. lateral view; b. edge view. 7. Brizalina panayensis, $1 \mathrm{H}-\mathrm{CC}$; a. lateral view; b. edge view. 8. Bolivinita quadrilatera, 61X-5, 115-117 cm; a. lateral view; b. edge view showing the asymmetrically positioned aperture. 9. Takayanagia cf. Takayanagia cushmani, 1H-CC; a. ventral view showing the tooth plate; b. dorsal view; c. edge view. 10. Rutherfordoides tenuis, $10 \mathrm{H}-3,146-148 \mathrm{~cm}$; a. ventral view; b. dorsal view. 11. Globocassidulina neomargareta, 9H-5, 146$148 \mathrm{~cm}$; a. ventral view; b. apertural view showing the tooth plate; c. dorsal view; d. edge view. 12. Globocassidulina subglobosa, 13H-3, 146-148 cm; a. ventral view; b. dorsal view; c. edge view. 13. Islandiella helenae, 12H-3, 146$148 \mathrm{~cm}$; a. ventral view; b. ventral view in immersion; c. dorsal view; d. edge view. 14. Globocassidulina sp. A, 3HCC; a. ventral side, b. dorsal side, c. edge view. 
1977 Bolivina panayensis McCulloch: p. 257, pl. 105, fig. 15.

Remarks. The overall morphology of this species is similar to Brizalina sphathula (Williamson, 1858) and Brizalina argentea (Cushman, 1926a), but it is different from the latter species by possessing clear costae. This form also resembles Brizalina subaenariensis (Cushman, 1922), but differs by possessing more costae and chambers and being more elongated.

Superfamily BOLIVINITACEA Cushman, 1927b

Family BOLIVINITIDAE Cushman, 1927b

Genus BOLIVINITA Cushman, 1927b

Bolivinita quadrilatera (Schwager, 1866)

Figure 3.8a, 3.8b

1866 Textularia quadrilatera Schwager: p. 253, pl. 7, fig. 103.

1884 Textularia quadrilatera Schwager; Brady, p. 358 , pl. 42, figs. 8-12.

1977 Bolivinita quadrilatera (Schwager); McCulloch, p. 254, pl. 105, fig. 27.

1994 Bolivinita quadrilatera (Schwager); Jones, p. 47, pl. 42, figs. 8-12.

1996 Bolivinita quadrilatera (Schwager); Revets, p. 6, pl. 1, figs. 1-4.

Description. Test elongated, tapered, biserial with a quadrate cross-section. Chambers increasing in size gradually. Sutures thick, oblique, flush or slightly elevated. Wall finely perforated. Apertural face depressed. Aperture an oval opening asymmetrically positioned near the base of the final chamber.

Superfamily CASSIDULINACEA d'Orbigny, 1839a Genus GLOBOCASSIDULINA Voloshinova, 1960 Globocassidulina neomargareta Finger and Lipps in Finger et al. (1990)

Figure 3.11a-d

1990 Globocassidulina neomargareta Finger and Lipps: p. 38, pl. 8, figs. 26, 27.

1990 Globocassidulina neomargareta Finger and Lipps; Finger, p. 112, plate-figs. 1-8.

Description. Test small, lenticular with a rounded periphery, biserially arranged and planispirally enrolled. Chambers inflated, increasing in size gradually. Sutures oblique, depressed. Wall finely perforated, smooth. Aperture a basal oval opening with a toothplate.

Remarks. The known range of this species in California is from the Oligocene to the Miocene (Finger, 1990).

Globocassidulina subglobosa (Brady, 1881)

Figure 3.12a-c
1881 Cassidulina subglobosa Brady: p. 60.

1884 Cassidulina subglobosa Brady; Brady, p. 430, pl. 54, fig. 17.

1994 Globocassidulina subglobosa (Brady); Jones, p. 60, pl. 54, fig. 17.

2012 Globocassidulina subglobosa (Brady); Milker and Schmiedl, p. 86, figs. 13-14.

Remarks. This form is much larger than Globocassidulina neomargareta Finger and Lipps (1990).

\section{Globocassidulina sp. A \\ Figure $3.14 \mathrm{a}-\mathrm{C}$}

Description. Test very large, planispirally coiled with biserially arranged chambers, about five pairs of chambers in the final whorl. Periphery angled. Chambers elongate, increasing in size gradually. Sutures flash in the early part, slightly depressed later. Wall thick, finely perforated. Aperture a basal arch without a tooth plate.

Remarks. Only three specimens, only one of which is complete, are recorded. It differs from Globocassidulina crassa (d'Orbigny, 1839b) by the shape of the aperture.

Genus ISLANDIELLA Nørvang, 1959

Islandiella helenae Feyling-Hanssen and Buzas, 1976

Figures 3.13a-d, 5.2a-c, 8.6

1976 Islandiella helenae Feyling-Hanssen and Buzas: p. 155, figs. 1-4.

1980 Islandiella helenae Feyling-Hanssen and Buzas; Rodrigues, Hooper, and Jones, $p$. 49 , pl. 1, figs. $1,3,5$, pl. 4 , figs $3,6,9$, pl. 6 , figs. $1,2$.

1983b Islandiella helenae Feyling-Hanssen and Buzas; Nomura, p. 16, pl. 2, figs. 4a-c, 5a-c, pl. 7, figs. 11, 12, pl. 8, figs 1, 2.

1999 Planocassidulina helenae (Feyling-Hanssen and Buzas); Nomura, p. 51, figs. 33$1 \mathrm{a}-\mathrm{c},-2 \mathrm{a}-\mathrm{c}, 36-1,-2$.

Remarks. The size and the convexity of test vary greatly among specimens. The identification criteria of the species in this study follow Nomura (1983b), and it is distinguished from Islandiella norcrossi (Cushman, 1933) by possessing roundedrhomboid to oval chambers, but not triangular chambers in mature specimens, and the different position of the aperture. Although the species was transferred to the genus Planocassidulina Gudina (1966) emended by Nomura (1999) from Islandiella by Nomura (1999) based on the acute and sometimes almost keeled periphery of $I$. helenae and $I$. norcrossi, the angle of periphery often varies among specimens, and they do not possess a 
proper keel. We therefore retain the species in the genus Islandiella.

Genus TAKAYANAGIA Nomura, 1983aTakayanagia delicata (Cushman, 1927a)

Figure $4.1 \mathrm{a}-\mathrm{c}$

1927a Cassidulina delicata Cushman: p. 168, pl. 6 , fig. 5 .

Description. Test small to medium, nearly circular in the side view, lenticular in the edge view, biserial, planispirally enrolled, with about four pairs of chambers in the final whorl, periphery angled. Chambers elongated, somewhat inflated, increasing in size gradually. Sutures clear, depressed. Wall finely perforate, smooth. Aperture a long slit along the base of the last chamber, without a tooth plate.

Remarks. This form may resemble Takayanagia cushmani, but differs in being more inflated and thicker in edge view and in the absence of a tooth plate.

Takayanagia cf. Takayanagia cushmani (Stewart and Stewart, 1930)

Figures 3.9a-c, 8.4

1930 Cassidulina cushmani Stewart and Stewart: p. 71, pl. 9, figs. 5a, b.

1982 "Islandiella" cushmani (Stewart and Stewart); Matoba and Yamaguchi, p. 1045, pl. 2, fig. 1a,b.

Remarks. The original description of the species by Stewart and Stewart (1930) mentions the presence of a slight tooth plate, and our specimens also possess a tooth plate that varies in size (see figs. 3.9a, 8.4). It differs from Takayanagia delicata (Cushman, 1927a) by possessing a more acute periphery and possessing a tooth plate, and from Cassidulina teretis Tappan (1951) by lacking umbilical bosses. It also differs from the typical Takayanagia cushmani by possessing a clear tooth plate. A very similar form was reported as "Islandiella cushmani" by Matoba and Yamaguchi (1982), which also possesses a Cassidulina-type aperture with a tooth plate.

Superfamily TURRILINACEA Cushman, 1927b Family TURRILINIDAE Cushman, 1927b

Subfaminly TURRILINIDAE Cushman, 1927b

Genus EUBULIMINELLA Revets, 1993 Eubuliminella exilis (Brady, 1884)

Figures 4.2, 8.7

1884 Bulimina elegans var. exilis Brady, p. 399, pl. 50, figs. 5, 6 .

1958 Bulimina exilis Brady: Asano, p. 3, pl. 3, figs. $7 \mathrm{a}, 7 \mathrm{~b}$.
1993 Eubuliminella exilis (Brady): Revets, p. 141 , pl. 1, figs. 1-7.

Remarks. Only the slender specimens with limbate sutures as noted by Revets (1993) are included.

Eubuliminella cf. Eubuliminella exilis (Brady, 1884) Figures 4.3, 8.8

1884 Bulimina elegans var. exilis Brady, p. 399, pl. 50, figs. 5,6 .

Remarks. This form differs from E. exilis by possessing much more inflated chambers which give a more lobulated outline and in lacking limbate sutures in the last chambers. Both $E$. exilis and this form coexist in the same samples, but the latter occurs only in two of the youngest samples, $1 \mathrm{H}-\mathrm{CC}$ and $3 \mathrm{H}-\mathrm{CC}$.

Superfamily BULIMINACEA Jones, 1875

Family BULIMINIDAE Jones, in Griffith and Henfrey, 1875

Bulimina rostratiformis McCulloch, 1977 Figure 4.5a, b

1977 Bulimina rostratiformis McCulloch, p. 245, pl. 104, fig. 8.

Remarks. The specimens in this study are much smaller than the type specimen.

Bulimina spicata Phleger and Parker, 1951 Figure 4.6

1951 Bulimina spicata Phleger and Parker: $p$. 16, pl. 7, figs. 25,30 .

Remarks. This species is different from Bulimina mexicana Cushman (1922) by its smaller size and less defined costae. It differs from Globobulimina cf. Globobulimina spinescens (Brady, 1884) in this study by its less elongated chambers and more stout and smaller test.

Genus GLOBOBULIMINA Cushman, 1927b

Globobulimina affinis (d'Orbigny, 1839a)

Figure 4.7

1839a Bulimina affinis d'Orbigny: p. 105, pl. 2, figs. 25, 26.

1992 Globobulimina affinis (d'Orbigny); Kaiho, pl. 4, figs. 6, 7 .

2001 Bulimina affinis (d'Orbigny); Szarek, p. 128, pl. 18, fig. 1.

Globobulimina auriculata (Bailey, 1851)

Figure 4.8

1851 Bulimina auriculata Bailey: p. 12, figs. 2527, 67.

1958 Globobulimina auriculata (Bailey); Asano, p. 9, pl. 2, figs. 1-3. 


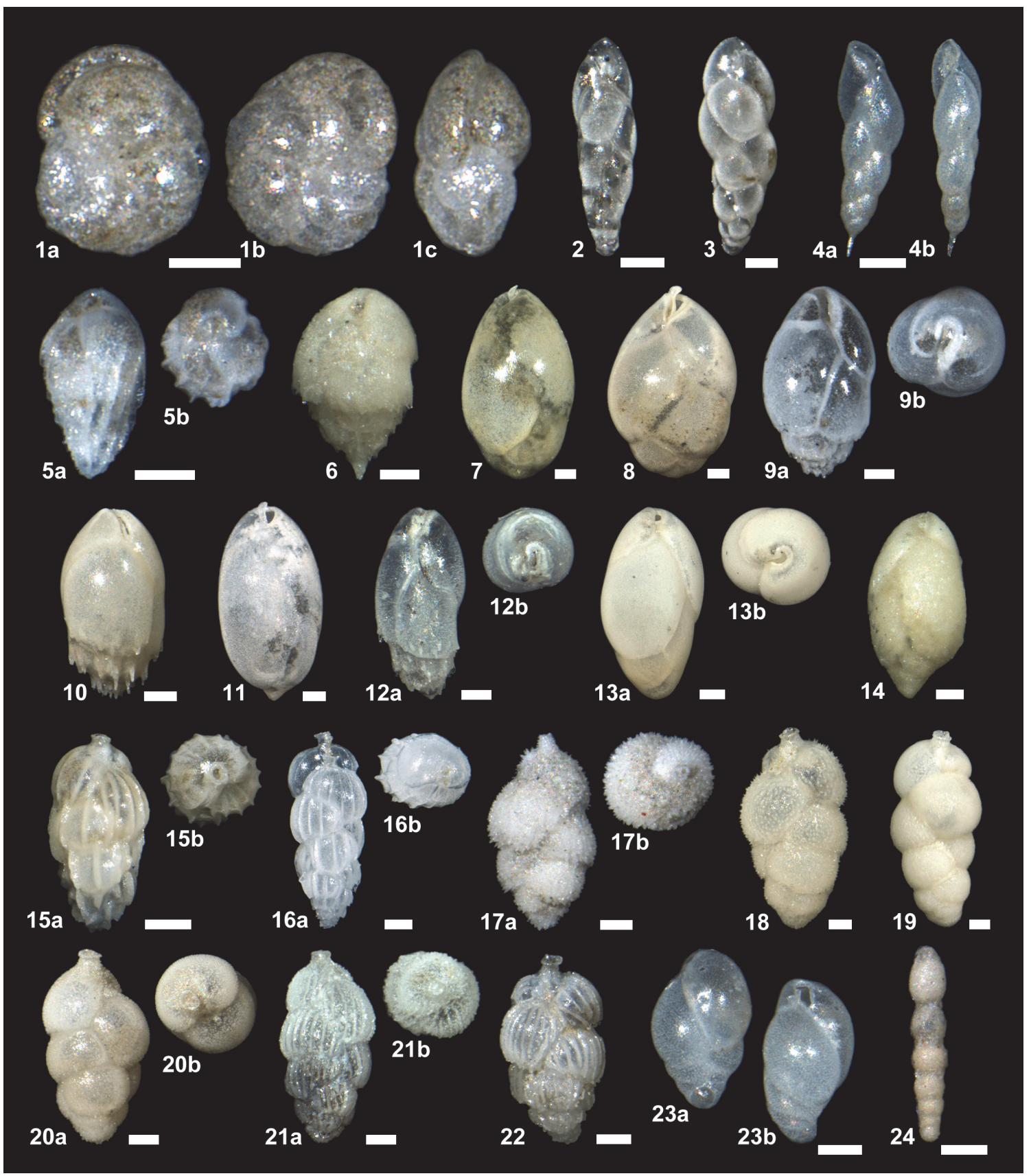

FIGURE 4. All scale bars are $100 \mu \mathrm{m}$. 1. Takayanagia delicata, 1H-CC; a. ventral view; b. dorsal view; c. edge view. 2. Eubuliminella exilis, $1 \mathrm{H}-\mathrm{CC}$, lateral view. 3. Eubuliminella cf. Eubuliminella exilis, $1 \mathrm{H}-\mathrm{CC}$, lateral view. 4. Fursenkoina complanata, $1 \mathrm{H}-\mathrm{CC}$, a. lateral view; b. edge view. 5. Bulimina rostratiformis, $8 \mathrm{H}-3,146-148 \mathrm{~cm}$; a. lateral view; b. apertural view. 6. Bulimina spicata, $62 \mathrm{X}-5,146-148 \mathrm{~cm}$, lateral view. 7. Globobulimina affinis, $8 \mathrm{H}-\mathrm{CC}$, lateral view. 8. Globobulimina auriculata, 25H-CC, lateral view. 9. Globobulimina barbata, $8 \mathrm{H}-3,146-148 \mathrm{~cm}$; a. lateral view; b. apertural view. 10. Globobulimina barbata, 52H-CC, lateral view. 11. Globobulimina cf. Globobulimina pacifica, $8 \mathrm{H}-\mathrm{CC}$, lateral view. 12. Globobulimina cf. Globobulimina spinenscens, 61X-5, 115-117 cm; a. lateral view; b. apertural view. 13. Globobulimina ovata, $18 \mathrm{H}-3,146-148 \mathrm{~cm}$; a. lateral view; b. apertural view. 14. Globobulimina ovata, 36H-5, 148-150 $\mathrm{cm}$, lateral view. 15. Uvigerina peregrina, 1H-CC; a. lateral view; b. apertural view. 16. Uvigerina peregrina, 3H-CC; a. lateral view; b. apertural view. 17. Uvigerina proboscidea, $12 \mathrm{H}-3,146-148 \mathrm{~cm}$; a. lateral view; b. apertural view. 18. Uvigerina proboscidea, $14 \mathrm{H}-\mathrm{CC}$, lateral view. 19. Uvigerina senticosa, $7 \mathrm{H}-\mathrm{CC}$, lateral view. 20. Uvigerina senticosa, $14 \mathrm{H}-\mathrm{CC}$; a. lateral view; b. apertural view. 21. Uvigerina interruptacostata, 3H-CC; a. lateral view; b. apertural view. 22. Uvigerina interruptacostata, $8 \mathrm{H}-3,146-148 \mathrm{~cm}$, lateral view. 23. Rutherfordoides erectus, $1 \mathrm{H}-\mathrm{CC}$; a. lateral view view; b. edge view. 24. Siphonodosaria sp. A, $36 \mathrm{H}-5,148-150 \mathrm{~cm}$, lateral view. 
1989 Globobulimina auriculata (Bailey); Revets, pl. 6 , figs. $1-4$.

Remarks. This form differs from other species of Globobulimina by possessing a large auricular apertural tongue.

Globobulimina barbata (Cushman, 1927a)

Figures 4.9a, 4.9b, 4.10

1927a Bulimina barbata Cushman: p. 151, pl. 2, fig. 11.

1960 Globobulimina barbata (Cushman); Uchio, pl. 6, fig. 6.

1992 Bulimina barbata (Cushman); Kaiho, pl. 4, fig. 8.

Remarks. This form differs from Globobulimina spinescens (Brady, 1884) by its more slender test and more prominent spines.

Globobulimina ovata (d'Orbigny, 1846)

Figures 4.13a, 4.13b, 4.14

1846 Bulimina ovata d'Orbigny: p. 185, pl. 11, figs. 13, 14.

1985 Praeglobobulimina ovata (d'Orbigny); p. 67 , pl. 21, fig. 3.

2006 Globobulimina ovata (d'Orbigny); Ortiz and Thomas, p. 118, pl. 6, figs. 4, 5 .

Description. Test elongated, slender, triserial with either rounded or pointed ends. Chambers elongated, increasing in size rapidly. Sutures clear, depressed, oblique. Wall finely perforate, smooth. Aperture basal, loop-shaped, with a small apertural tongue.

Remarks. This form is more elongated and slender with the last two more embracing chambers, which comprise three quarters of the total length of the test, than Globobulimina affinis. It differs from Globobulimina pacifica by being more elongate and possessing more than three chambers externally visible. The specimens in this study resemble the Eocene specimen of Globobulimina ovata (d'Orbigny, 1846) illustrated by Ortiz and Thomas (2006, pl. 6, fig. 5a, b), but differ from the type specimen of $G$. ovata by its more overlapping and elongated chambers, less incised sutures, and possessing less chambers externally visible.

\section{Globobulimina cf. Globobulimina pacifica \\ Cushman, 1927b \\ Figure 4.11}

1927b Globobulimina pacifica Cushman: p. 67, pl. 14, fig. 12.

Remarks. This species is similar to Golobobulimina pacifica in possessing three strongly overlapping chambers, but differs in its more elongated, slender test. It differs from Praeglobobulimina ovata (d'Orbigny, 1846) by its more strongly overlapping chambers and possessing fewer chambers (about three) visible externally, and from Globobulimina ovula (d'Orbigny, 1839) in the more slender test with less inflated chambers.

Globobulimina cf. Globobulimina spinescens (Brady, 1884)

Figure $4.12 \mathrm{a}, 4.12 \mathrm{~b}, 8.10$

1884 Bulimina pyrula d'Orbigny var. spinescens Brady: p. 400, pl. 50, figs. 11, 12.

1958 Globoulimina spinescens (Brady); Asano, p. 12, pl. 3, figs. 1, 2 .

1980 Bulimina aff. pyrula spinescens Brady; Butt, pl. 8, fig.22, pl. 9, fig. 30.

Remarks. The specimens in this study resemble the specimens illustrated by Asano (1958) and Butt (1980), which is more elongated and slender than the typical broad forms.

Family UVIGERINIDAE Haeckel, 1894

Subfamily UVIGERININAE Haeckel, 1894

Genus UVIGERINA d'Orbigny, 1826

Uvigerina interruptacostae LeRoy, 1944

Figures 4.21a, 4.21b, 4.22

1944 Uvigerina interrupta-costae LeRoy: p. 31, pl. 8, fig. 44.

1986 Uvigerina interrupta-costae LeRoy; Boersma, p. 990, pl. 20, fig. 7.

Remarks. The specimens in this study possess numerous fine costae with small pustules between. Costae are restricted to each chamber, and sometimes broken into segments. It differs from Uvigerina peregrina Cushan (1923) by its more numerous and finer costae.

Uvigerina peregrina Cushman, 1923

Figures 4.15a, 4.15b, 4.16a, 4.16b

1923 Uvigerina peregrina Cushman: p. 166, pl. 42, figs. 7-10.

1950 Uvigerina akitaensis Asano: p. 14, pl. 14, figs. 60-62.

1984 Uvigerina peregrina Cushman; Boersma, p. 124, pl. 1, figs. $1-4$.

1986 Uvigerina peregrina Cushman; Lutze, 1986 , p. 32, figs. $1-6$.

Remarks. Many of the specimens in this study are elongated and slender resembling Uvigerina akitaensis Asano (1950). It has been, however, shown that $U$. peregrina exhibits a high morphological plasticity based on morphological analysis (Van der Zwaan et al., 1986) and molecular phylogeny analysis (Schweizer et al., 2005), and thus we follow 
the suggestion by Scott (Scott et al., 2000) and Schweizer (2006) that $U$. akiataensis is a synonym of $U$. peregrina.

Uvigerina proboscidea Schwager, 1866

Figures 4.17a, 4.17b, 4.18, 8.11

1866 Uvigerina proboscidea Schwager: p. 250, pl. 7, fig. 96.

1986 Uvigerina proboscidea Schwager; van Morkhoven, Berggren and Edwards, p. 28, pl. 6, figs. 1-4.

Remarks. Specimens with a hispid wall are included here, whereas individuals with the papillose wall are included in Uvigerina senticosa (Cushman, 1927a). The specimens resembles Uvigerina auberiana d'Orbigny (1826) with its hispid wall, but differs in its lager test size and lacking the truly biserial portion in the late growth stage.

Uvigerina senticosa Cushman, 1927a

Figures 4.19, 4.20a, 4.20b, 8.12

1927a Uvigerina senticosa Cushman: p. 159, pl. 3, fig. 14.

1980 Uvigerina senticosa Cushman; Thompson, pl. 8, fig. 11.

1992 Uvigerina senticosa Cushman; Kaiho, pl. 4, fig. 12.

Remarks. Specimens with a papilose and an only slightly papillose wall are included. Small, smoothwalled specimens with the papillose to hispid early part are also included here. These small specimens are probably juveniles, and almost confined to the uppermost part of the studied interval.

Family FURSENKOINIDAE Loeblich and Tappan, 1961

Fursenkoina complanata (Egger, 1893)

Figures $4.4 a, 4.4 b, 8.9$

1884 Virgulina schreibersiana Cžjzek; Brady, p. 414, pl. 52, figs. 1-3.

1893 Virgulina schreibersiana Cžjzek var. complanata Egger: p. 292, pl. 8, figs. 91, 92.

1958 Virgulina complanata Egger; Asano, p. 14, pl. 3, fig. 8.

1994 Fursenkoina complanata (Egger); Jones, p. 56 , pl. 52, figs. $1-3$.

2012 Stainforthia complanata (Egger); Milker and Schmiedl, p. 86, fig. 20.16.

2013 Fursenkoina complanata (Egger); Holbourn, Henderson and MacLeod, p. 258.

Remarks. The specimens in this study possess a twisted, biserial early portion, not triserial.
Genus RUTHERFORDOIDES McCulloch, 1981

Rutherfordoides erectus (Cushman and Renz, 1941)

Figures 4.23a, 4.23b, 8.13

1941 Cassidulinoides erecta Cushman and Renz: p. 25, pl. 4, figs. 6, 7.

1985 Rutherfordoides erecta (Cushman and Renz); Kohl, p. 89, pl. 18, fig. 2.

1999 Rutherfordoides erecta (Cushman and Renz); Nomura, p. 56, figs. 29-9, -10, -11, 12, 30-12, 38, 39.

Rutherfordoides tenuis (Phleger and Parker, 1951) Figures 3.10a, 3.10b, 8.5

1951 Cassidulinoides tenuis Phleger and Parker: p. 27, pl. 14, figs. 14-17.

1967 Evolvocassidulina tenuis (Phleger and Parker); Eade, p. 433, fig. 3.3, 4.

1985 Rutherfordoides tenuis (Phleger and Parker); Kohl, p. 89, pl. 18, fig. 5.

Remarks. Some mature specimens are as elongated as the type specimens. The specimens do not possess a prominent tooth plate. The early portions is only arched and not coiled fully as in the genus Evolvocassidulina. Juvenile forms of this species may resemble Rutherfordoides erectus (Cushman and Renz), but differ by its more rounded cross section, and chambers which are overlapping less and possess blunt rounded ends.

Superfamily STILOSTOMELLACEA Finlay, 1947

Family STILOSTOMELLIDAE Finlay, 1947

Genus SIPHONODOSARIA Silvestri, 1924

Siphonodosaria? sp. A

Figures 4.24, 8.14

Description. Test elongated, uniserial with several chambers. Chambers globular in the early part and more ovoid in the later part, inflated, increasing in size rapidly, not tightly arranged. Wall rough. Aperture on a neck with a lip.

Remarks. The apertural features are not visible in the specimens, thus it is not clear whether it belongs to the genus Siphonodosaria or Strictocostella. It is rare, and its last occurrence is observed in sample $36 \mathrm{H}-5,148 / 150 \mathrm{~cm}$.

\section{Siphonodosaria? sp. B}

Figure 8.15

Remarks. This form is superficially similar to Siphonodosaria bradyi (Cushman, 1927b) with a row of spines, but the aperture is not visible. It is rare, and its last occurrence is observed in sample $13 \mathrm{H}-5,146 / 148 \mathrm{~cm}$.

Siphonodosaria? spp. 
Remarks. Broken specimens, often single-chambered, are included.

Genus STILOSTOMELLA Guppy, 1894

Stilostomella fistuca (Schwager, 1866)

Figure 8.16

1884 Nodosaria subtertenuata Schwager; Brady, p. 507, pl. 62, figs. 7, 8.

1866 Nodosaria fistuca Schwager: p. 216, pl. 5, figs. 36, 37.

1994 Stilostomella fistuca: Jones, p. 73, pl. 62, figs. 7,8 , supplementary plate 2 , figs. 12 , 13.

2002 Stilostomella fistuca (Schwager): Hayward, p. 306, pl. 3, figs. 41-45.

2012 Stilostomella fistuca (Schwager): Hayward, Kawagata, Sagaa, Grenfell, van Kerckhoven, Johnson and Thomas, p. 183, pl. 20 , figs $1-14$.

Remarks. This species possesses ovoidal chambers which are loosely attached and a pustulose test surface. It is very rare, and its last occurrence is observed in Sample 13H-CC in Hole U1341B.

Superfamily DISCORBACEA Ehrenberg, 1838

Family BAGGINIDAE Cushman, 1927b

Subfamily BAGGININAE Cushman, 1927b

Genus VALVULINERIA Cushman, 1926a

Valvulineria cf. Valvulineria sadonica Asano 1951

Figure 5.1a-c

1951 Valvulineria sadonica Asano; p. 8, figs. 55-57.

1963 Valvulineria sadonica Asano: Matsunaga, pl. 45, fig. 1.

2000 Valvulinera sadonica Asano: Scott, Takayanagi, Hasegawa, and Saito, p. 37, Fig. 14.273-275.

Remarks. It differs from Valvulineria sadonica by apertural flaps covering almost entirely the umbilicus which somehow resemble imbricated portici in planktic foraminifera (see Norris, 1992). It differs from Valvulineria mexicana Parker (1954) by its smaller flaps.

\section{Valvulineria spp.}

Remarks. Small specimens which may belong to the genus are included.

Family EPONIDIDAE Hofker, 1951

Subfamily EPONIDINAE Hofker, 1951

Genus ALABAMINELLA Saidova, 1975

Alabaminella weddellensis (Earland, 1936)

Figure 5.3a-c
1936 Eponides weddellensis Earland: p. 57, pl. 1, figs. 65-67.

Description. Test very small, biconvex, low trochospiral, tightly coiled with five chambers in the final whorl. Umbilicus closed. Periphery subangular. Chambers elongated on the spiral side, triangular on the umbilical side, increasing in size gradually. Sutures clear, depressed, slightly curved on the spiral side, radial and straight on the umbilical side. Wall finely perforated. Aperture a basal arch near the peripheral edge, continuing as a basal slit to the umbilicus.

Remarks. The specimens in this study are also similar to Eponides (?) cf. Eponides pusillus (Parr) described by McCulloch (1977) which may actually belong to Alabaminella weddellensis.

Superfamily DISCORBINELLACEA Sigal, 1952

Family PARRELLOIDIDAE Hofker, 1956

Genus PARRELLOIDES Hofker, 1956

Parrelloides healdi (Stewart and Stewart, 1930)

Figures 5.6a-c, 5.7a-c

1930 Eponides healdi Stewart and Stewart: p. 70, pl. 8, fig. 8.

1990 Gyroidina healdi (Stewart and Stewart); Finger, 118, plate-figs. 1-9.

1992 Gyroidina healdi (Stewart and Stewart); Finger, p. 88, pl. 36, figs. 1-6.

Description. Test of medium size, low trochospiral, tightly coiled, biconvex, circular in outline, with seven and a half to nine chambers in the final whorl and a closed umbilicus. Periphery rounded to slightly pinched. Sutures flush, slightly curved backwards on the spiral side, straight on the umbilical side. A small basal pore-like aperture with a slight lip. The aperture is placed in the middle of the apertural face between the umbilicus and periphery and does not extend to or position at the periphery.

Remarks. This form is superficially similar to Hansenisca sp. A, but differs in possessing a closed umbilicus and only one aperture and being more biconvex. It also differs from Parrelloides densus Saidova (1975) in possessing sutures that are curved backwards and the more acute periphery. The known range of this species in California is from the Oligocene to the Pliocene (Finger, 1990).

$$
\begin{gathered}
\text { Family PSEUDOPARRELLIDAE Voloshinova in } \\
\text { Voloshinova and Dain, } 1952 \\
\text { Subfamily PSEUDOPARRELLINAE Voloshinova in } \\
\text { Voloshinova and Dain, } 1952 \\
\text { Genus EPISTOMINELLA Husezima and Maruhasi, } \\
1944 \\
\text { Epistominella pulchella Husezima and Maruhasi, }
\end{gathered}
$$




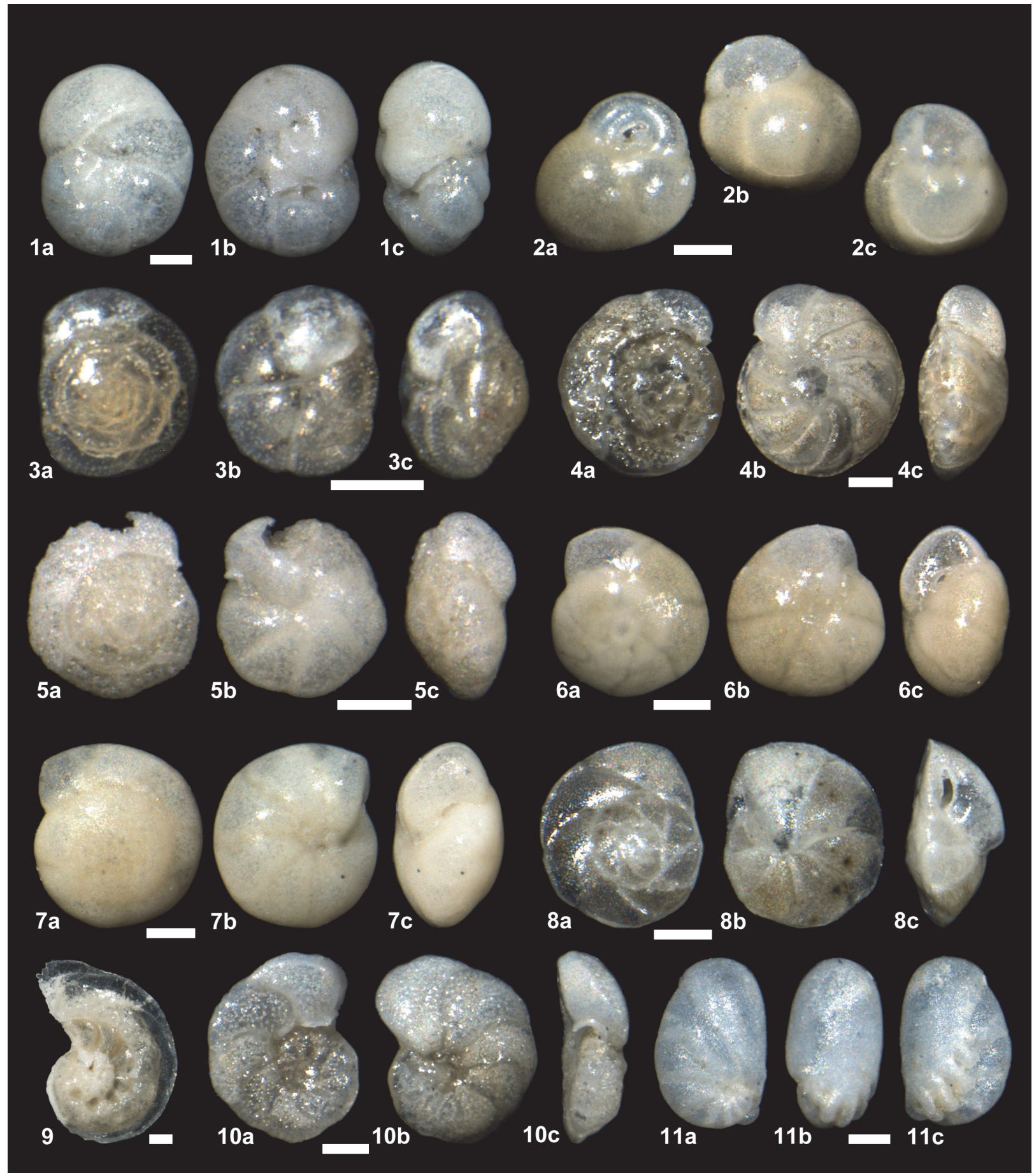

FIGURE 5. All scale bars are $100 \mu \mathrm{m}$. 1. Valvulineria cf. Valvulineria sadonica, 4H-CC; a. dorsal view; b. ventral view; c. edge view. 2. juvenile form of Islandiella helenae?, 1H-CC; a. ventral view; b. dorsal view; c. edge view. 3. Alabaminella weddellensis, $13 \mathrm{H}-3,146-148 \mathrm{~cm}$; a. dorsal view; b. ventral view; c. edge view. 4. Cibicidoides mundulus, $18 \mathrm{H}-$ 3, 146-148 cm; a. ventral view; b. dorsal view; c. edge view. 5. Cibicidoides simplex, 1H-CC; a. ventral view; b. dorsal view; c. edge view. 6. Parrelloides healdi, 1H-CC; a. dorsal view; b. ventral side view; c. edge view showing the porelike aperture. 7. Parrelloides healdi, $25 \mathrm{H}-5,146-148 \mathrm{~cm}$; a. spiral view; b. umbilical view; c. edge view showing the pore-like aperture. 8. Epistominella pulchella, 4H-CC; a. spiral view; b. umbilical view; c. edge view showing the elongate arch aperture. 9. Laticarinina pauperata, 52H-CC. 10. Cibicidoides wuellerstorfi, 10H-3, 146-148 cm; a. ventral view; b. dorsal view; c. edge view. 11. Nonionella digitata, 9H-5, 146-148 cm; a. dorsal view; b. edge view; c. ventral side. 
1944

Figure 5.8a-c

1944 Epistominella pulchella Husezima and Maruhashi: p. 398, pl. 34, fig. 10.

1992 Epistominella pulchella Husezima and Maruhashi; Kato, p. 386, pl. 3, figs. 2-4.

Description. Test small to medium, low trochospiral with seven chambers in the final whorl. The umbilical side is more inflated than the spiral side, which is only slightly convex. Periphery acute. Umbilicus closed. Chambers increasing in size gradually. Sutures clear, depressed, curved backwards on the spiral side, less so on the umbilical side. Wall smooth, finely perforated. Aperture an elongate arch at the base of the last chamber. Apertural face somewhat dented.

Remarks. This species is very similar to Epistominella smithi (Stewart and Stewart, 1930) described from the lower Pliocene of California, but based on the definition the former differs from the latter by possessing more chambers in the final whorl (seven instead of five to six) and E. smithi seems to have a more prominent keel. It differs from Epistominella exigua (Brady, 1884) by its planoconvex test and less lobulated periphery.

Family DISCORBINELLIDAE Sigal in Piveteau, 1952

Subfamily DISCORBINELLINAE Sigal in Piveteau, 1952

Genus LATICARININA Galloway and Wissler, 1927

Laticarinina pauperata (Parker and Jones, 1865) Figures 5.9, 8.17

1865 Pulvinulina repanda Fichtel and Moll var. menardii d'Orbigny subvar. pauperata Parker and Jones: p. 395, pl. 16, figs. 50, 51.

1884 Pulvinulina pauperata Parker and Jones: Brady, p. 696, pl. 104, figs. 3-11.

1985 Laticarinina pauperata (Parker and Jones): Kohl, p. 77, pl. 26, fig. 1.

1994 Laticarinina pauperata (Parker and Jones): Jones, p. 104, pl. 104, figs. 3-11.

2013 Laticarinina pauperata (Parker and Jones): Holbourn, Henderson and MacLeod, p. 328 , figs. $1,2$.

Remarks. The specimens in this study are biconvex and not as evolute as those illustrated by other studies. The keel is broader than the height of the final chambers, as depicted in the original illustrations by Parker and Jones.
Superfamily PLANORBULINACEA Schwager, 1877

Family CIBICIDIDAE Cushman, 1927b

Genus CIBICIDOIDES Saidova, 1975

Cibicidoides mundulus (Brady, Parker, and Jones, 1888) emend. Loeblich and Tappan, 1955

Figure $5.4 \mathrm{a}-\mathrm{C}$

1884 Truncatulina, sp., intermediate form near Truncatulina haidingerii d'Orbigny; Brady, pl. 95, fig. 6.

1888 Truncatulina mundula Brady, Parker, and Jones: p. 228, pl. 45, fig. 25

1955 Cibicidoides mundula (Brady, Parker, and Jones) emend. Loeblich and Tappan: $p$. 25, pl. 4, fig. 4.

1994 Cibicidoides mundulus (Brady, Parker and Jones): Jones, p. 99, pl. 95, fig. 6.

1996 Cibicidoides mundulus (Brady, Parker and Jones): Revets, p. 65, pl. 1, figs. 9-12.

2013 Cibicidoides mundulus (Brady, Parker and Jones): Holbourn, Henderson and MacLeod, p. 196, figs. 1-8.

Remarks. The specimens in this study clearly resemble those illustrated by Loeblich and Tappan (1955) and Holbourn et al. (2013) in possessing an umbilical boss that was not illustrated by Brady et al. (1888). Although the genus Cibicidoides is placed under the family Parrelloididae by Loeblich and Tappan (1987), it is assigned to the family Cibicididae in this study following Schweizer et al. (2009)

Cibicidoides simplex McCulloch, 1977 Figure 5.5a-c

1977 Cibicidoides (?) simplex McCulloch: p. 447, pl. 152, fig. 12.

Remarks. This species is characterised by its biconvex text with a bluntly angled periphery, a prominently perforated wall and sutures which are flush to only slightly depressed. The specimens in this study are smaller than the type specimen described by McCulloch (1977).

Cibicidoides wuellerstorfi (Schwager, 1866)

Figure 5.10a-c

1866 Anomalina wüllerstorfi Schwager: p. 258, pl. 7, figs. 105, 107.

1884 Truncatulina wuellerstorfi (Schwager); Brady, p. 662, pl. 93, figs. 8, 9.

1963 Planulina wuellerstorfi (Schwager); Matsunaga, pl. 50, fig. 7.

1980 Cibicides wuellerstorfi (Schwager); Thompson, pl. 7, figs. 7, 8. 
1994 Cibicidoides wuellerstorfi (Schwager); Jones, p. 98, pl. 93, figs. 8, 9.

1994 Fontbotia wuellerstorfi (Schwager); Loeblich and Tappan, p. 150, pl. 319, figs. 713.

2013 Planulina wuellerstorfi (Schwager); Holbourn, Henderson, and MacLeod, p. 416.

Remarks. This species has recently been assigned to three different genera. It is the type species of the genus Fontbotia, which was considered as a subjective sysnonym of the genus Planulina by Revets (1996). This species is assigned to the genus Cibicidoides in this study following the results of molecular phyogenetic studies by Schweizer (2006) and Schweizer et al. (2009, 2011).

Superfamily NONIONACEA Schultze, 1854

Family NONIONIDAE Schultze, 1854

Subfamily NONIONINAE Schultze, 1854

Genus NONIONELLA Cushman, 1926a

Nonionella digitata Nørvang, 1945

Figures 5.11a-c, 8.18

1945 Nonionella turgida (Williamson) var. digitata Nørvang: p. 29, text-fig. 4.

2007 Nonionella digitata Nørvang; Vázquez Riveiros and Patterson, p. 29, fig. 12.5.

Remarks. This form can be differentiated from the other species of Nonionella by its umbilical flap with long digitate extensions. The umbilical flap is much more prominent with longer extensions than that of Nonionella stella Cushman and Moyer (1930). The digitate flap can be observed with juveniles.

Nonionella turgida (Williamson, 1858)

1858 Rotalina turgida Williamson: p. 50, pl. 4, figs. 95-97.

1884 Nonionina turgida (Williamson); Brady, p. 731, pl. 109, figs. 17-19.

1994 Nonionella turgida (Williamson); Jones, p. 108, pl. 109, figs. 17-19.

Remarks. This form is quite rare in our samples, and only broken specimens are recorded. It differs from the other species by its smaller and thinner test with more numerous, elongated chambers.

\section{Nonionella spp.}

Remarks. Small specimens, probably juveniles of one of the species of Nonionella and Nonionellina identified in this study, are included here.

\section{Genus NONIONELLINA Voloshinova, 1958}

Nonionellina labradorica (Dawson, 1860)

Figures 6.1a, b, 8.19
1860 Nonionina labradorica Dawson: p. 191, text-fig. 4.

1963 Nonion labradricum (Dawson); Matsunaga, pl. 37, fig. 4.

1967 Nonion labradricum (Dawson); Matoba, pl. 29, fig. 7.

1980 Nonion labradoricum (Dawson); Keller, pl. 3, figs. 9, 10.

2007 Nonionellina labradorica (Dawson); Vázquez Riveiros and Patterson, p. 29, fig. 12.7.

2013 Nonionellina labradorica (Dawson); Holbourn, Henderson and MacLeod, p. 374.

Remarks. The outline of the specimens in this study is not lobulated as the specimen illustrated by Dawson (1860). They have a smooth outline as in the specimens from the Pacific illustrated by Matsunaga (1963), Matoba (1967) and Vázquez Riveiros and Patterson (2007), though a form with a lobulated outline has been recorded in the Pacific, e.g., in the Japan Trench area (Keller, 1980).

Nonionellina cf. Nonionellina labradorica (Dawson, 1860)

Figures 6.2a, b, 8.20

1860 Nonionina labradorica Dawson: p. 191, text-fig. 4.

Remarks. This form is smaller and thinner than Nonionellina labradorica. The chambers in this form increase in size more slowly than in N. labradorica. Both forms coexist, but in some samples only the small form is observed. It might be a juvenile of $N$. labradorica.

Subfamily ASTRONONIONINAE Saidova, 1981

Genus ASTRONONION Cushman and Edwards, 1937

Astrononion stellatum Cushman and Edwards, 1937

Figure 6.3a-c

1937 Astrononion stellatum Cushman and Edwards: p. 32, pl. 3, figs. 9-11.

Description. Test small, planispiral, involute, with seven chambers in the final whorl, lobulate in outline. Periphery rounded. Chambers inflated, increasing in size gradually, with a plate extending into the umbilicus. Sutures depressed. Wall smooth, finely perforate. Aperture an interiomarginal slit.

Remarks. It differs from Astrononion stelligerum (d'Orbigny, 1839a) by possessing fewer chambers in the final whorl. 


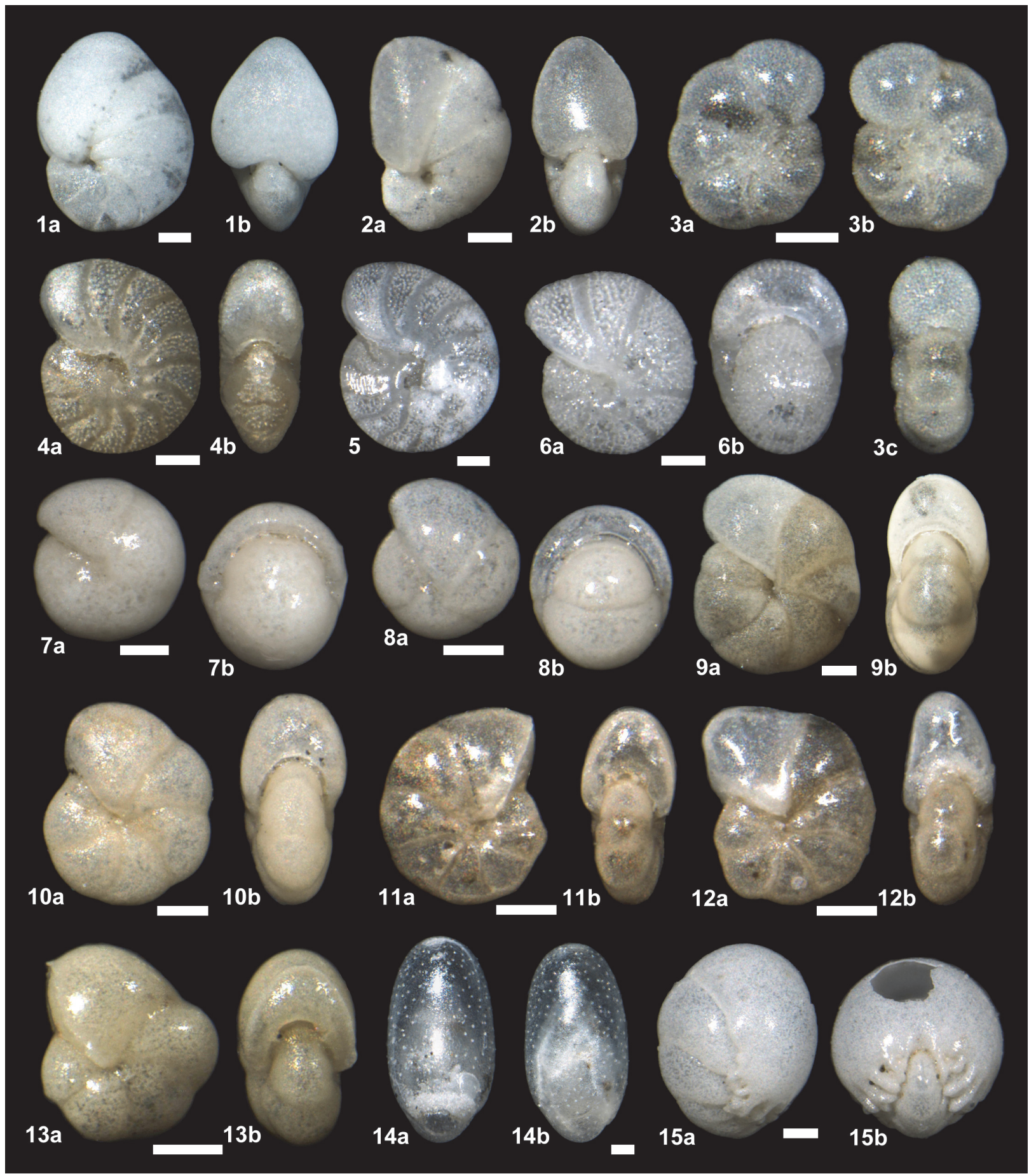

FIGURE 6. All scale bars are $100 \mu \mathrm{m}$. 1. Nonionellina labradorica, 3H-CC; a. lateral left view; b. edge view. 2. Nonionellina cf. Nonionellina labradorica, $15 \mathrm{H}-5,146-148 \mathrm{~cm}$; a. lateral left view; b. edge view. 3. Astrononion stellatum, $10 \mathrm{H}-\mathrm{CC} ; \mathrm{a}$. lateral fight view; b. lateral left view; c. edge view. 4. Melonis affinis, $1 \mathrm{H}-\mathrm{CC}$; a. lateral left view; b. edge view. 5. Melonis affinis, $9 \mathrm{H}-5,146-148 \mathrm{~cm}$. 6. Melonis pompilioides, $1 \mathrm{H}-\mathrm{CC}$; a. lateral left view; b. edge view. 7. Pullenia bulloides, $11 \mathrm{H}-3,146-148 \mathrm{~cm}$; a. lateral left view; b. apertural view. 8. Pullenia bulloides, 12H-3, 146-148 cm; a. lateral left view; b. apertural view. 9. Pullenia cf. Pullenia catalinaensis, 36H-CC; a. lateral left view; b. edge view. 10. Pullenia cf. Pullenia catalinaensis, 9H-5, 146-148 cm; a. lateral left view; b. edge view. 11. Pullenia elegans, 13H-3, $146-148 \mathrm{~cm}$; a. lateral right view; b. edge view. 12. Pullenia elegans, $13 \mathrm{H}-3,146-148 \mathrm{~cm}$; a. lateral left view; b. edge view. 13. Pullenia salisburyi, $26 \mathrm{H}-5,147-149 \mathrm{~cm}$; a. lateral left view; b. edge view. 14. Chilostomella ovoidea, $2 \mathrm{H}-\mathrm{CC}$, a. ventral view; b. dorsal view. 15. Chilostomella cf. Chilostomella fimbriata, $10 \mathrm{H}-3,146-148 \mathrm{~cm}$; a. lateral right view; b. edge view. 
Subfamily PULLENIINAE Schwager, 1877

Genus MELONIS de Montfort, 1808

Melonis affinis (Reuss, 1851)

Figures $6.4 a, b, 6.5$

1858 Nonionina barleeana Williamson: p. 32, pl. 3, figs. 68, 69.

1884 Nonionina umbilicatula (Montagu); Brady, p. 726 , pl. 109, figs. $8,9$.

1994 Melonis affinis (Reuss); Jones, p. 107, pl. 109, figs. 8, 9.

1994 Melonis barleeanus (Williamson); Loeblich and Tappan, p. 157, pl. 347, figs. 1-5.

2001 Melonis affinis (Reuss); Szarek, p. 143, pl. 23, figs. 12-14.

2012 Melonis affinis (Reuss); Milker and Schmiedl, p. 115, fig. 26.9-10.

2012 Melonis barleeanum (Willamson); Milker and Schmiedl, p. 115, fig. 26.11-12.

2013 Melonis barleeanum (Williamson); Holbourn, Henderson, and MacLeod, p. 354.

Remarks. Most of the specimens found in this study are similar to Melonis affinis illustrated by Milker and Schmiedl (2012), who distinguished this species from $M$. barleeanum by its less prominent apertural lip. Based on molecular analysis, Schweizer (2006) synonymised Melonis barleeanus under Melonis affinis. The genus Melonis is suggested to belong to the family Cibicididae based on its closer relationship to cibicidids than to the genus Pullenia revealed by the molecular phylogenetic study by Schweizer et al. (2009). The genus Melonis is, however, retained in the subfamily Pulleniinae under the family Nonionidae because of its plasnispiral coiling mode, which does not agree with the morphological definition of the family Cibicididae.

Melonis pompilioides (Fichtel and Moll, 1798) Figure 6.6a, b

1798 Nautilus pompilioides Fichtel and Moll: p. 31, pl. 2, figs. a-c.

1884 Nonionina pompilioides (Fichtel and Moll); Brady, p. 727, pl. 109, figs. 10, 11.

1976 Melonis pompilioides (Fichtel and Moll); Pflum and Frerichs, p. 122, pl. 7, figs. 7, 8.

1979 Melonis pompilioides (Fichtel and Moll); Corliss, p. 12, pl. 5, figs. 9, 10.

1994 Melonis pompilioides (Fichtel and Moll); Jones, p. 108, pl. 109, figs. 10, 11.

Remarks. This species differs from Melonis affinis by possessing a much thicker test with a broadly rounded periphery. The specimens in this study are assigned to Melonis pompilioides rather than to Melonis spheroides (Voloshinova, 1958) following the remarks by Belanger and Berggren (1986) that $M$. spheroides is more involute and possesses narrower and shallower umbilici, indistinct sutures and larger pores. Van Morkhoven et al. (1986) regarded the two species to be synonymous.

Genus PULLENIA Parker and Jones, in Carpenter, Parker and Jones 1862

Pullenia bulloides (d'Orbigny, 1846)

Figures $6.7 \mathrm{a}, 6.7 \mathrm{~b}, 6.8 \mathrm{a}, 6.8 \mathrm{~b}$

1846 Nonionina bulloides d'Orbigny: p. 107, pl. 5, figs. 9, 10.

1884 Pullenia sphaeroides d'Orbigny; Brady, p. 615, pl. 84, figs. 12, 13.

1963 Pullenia bulloides (d'Orbigny); Matsunaga, pl. 49, fig. 9.

1985 Pullenia bulloides (d'Orbigny); Kohl, p. 92, pl. 32, fig. 5.

1994 Pullenia bulloides (d'Orbigny); Jones, p. 92, pl. 84, figs. 12, 13.

Remarks. Specimens with a broad periphery and four to five chambers in the final whorl are included.

Pullenia cf. Pullenia catalinaensis McCulloch, 1977 Figures 6.9a, b, 6.10a, b

1977 Pullenia catalinaensis McCulloch: p. 436, pl. 171, fig. 4.

Description. Test of medium size, planispiral, with five and a half to six and a half chambers in the final whorl. Umbilicus small. Periphery rounded, lobulated. Chambers increasing in size gradually. Sutures distinct, depressed, sinuous, or curved backwards. Wall finely perforated, smooth. Aperture a basal slit with a lip.

Remarks. The specimens in this study are smaller than the type specimen, which is ca. $1 \mathrm{~mm}$ in the maximum diameter, and appear to be more highly perforated. McCulloch depicts a specimen that appears to be shinier, without visible pores. The species differs from Pullenia bulloides in its more laterally compressed test, higher number of chambers, and curved sutures and from Pullenia quinqueloba (Reuss, 1851) by possessing a more rounded periphery and more than five chambers in the final whorl.

Pullenia elegans Cushman and Todd, 1943 Figures 6.11a, b, 6.12a, b

1943 Pullenia elegans Cushman and Todd: $p$. 23, pl. 4, fig. 11. 
1973 Pullenia elegans Cushman and Todd; Lankford and Phleger, p. 125, pl. 6, fig. 9.

1977 Pullenia elegans McCulloch, p. 437, pl. 171, fig. 1.

Remarks. This form is laterally compressed and possesses a subarcuate and lobulate periphery, about seven chambers in the final whorl, and curved sutures. It differs from Pullenia quinqueloba by possessing more than five chambers.

Pullenia salisburyi Stewart and Stewart, 1930

Figure 6.13a, b

1930 Pullenia salisburyi Stewart and Stewart: $\mathrm{p}$. 72, pl. 8, fig. 2.

1973 Pullenia salisburyi Stewart and Stewart; Lankford and Phleger, p. 125, pl. 6, fig. 10.

Remarks. This form is different from Pullenia elegans by being smaller and possessing fewer chambers in the final whorl and a last chamber which is much larger than the previous chambers. It resembles Pullenia quinqueloba with five chambers in the final whorl, but differs in possessing a disproportionately large last chamber.

Superfamily CHILOSTOMELLACEA Brady, 1881

Family CHILOSTOMELLIDAE Brady, 1881

Subfamily CHILOSTOMELLINAE Brady, 1881

Genus CHILOSTOMELLA Reuss in Cžjzek, 1849 Chilostomella ovoidea Reuss, 1850

Figure 6.14a, b

1850 Chilostomella ovoidea Reuss: p. 380, pl. 48, fig. 12.

1994 Chilostomella ovoidea Reuss; Loeblich and Tappan, p. 160, pl. 350, figs. 1-3.

Remarks. The specimens in this study are not as broad as the specimen illustrated by Reuss (1850), but not as elongated and slender as Chilostomella oolina Schwager (1878). They are similar to the specimen from the western Timor Sea illustrated by Loeblich and Tappan (1994).

Genus CHILOSTOMELLINA

Chilostomellina cf. Chilostomellina fimbriata Cushman, 1926b

Figure $6.15 a, b$

1926b Chilostomellina fimbriata Cushman: p.78, pl. 11, fig. 22.

1980 Chilostomellina fimbriata Cushman; Keller, pl. 2, figs. 6,7 .

Remarks. The only specimen in this study is broken, but possesses an apertural margin, which is more fimbriate than the specimens illustrated by Cushman (1926b, 1928) and Hoskin and Haskins
(1975). The form identified in this study resembles the specimen illustrated by Keller (1980).

Family QUADRIMORPHINIDAE Saidova, 1981 Genus QUADRIMORPHINA Finlay, 1939

Quadrimorphina laevigata (Phleger and Parker, 1951)

Figure $7.1 \mathrm{a}-\mathrm{c}$

1951 Valvulineria laevigata Phleger and Parker: p. 25, pl. 13, figs. 11, 12.

1982 Quadrimorphina laevigata (Phleger and Parker); Matoba and Yamaguchi, p. 1048, pl. 4, fig. 2.

2000 Quadrimorphina laevigata (Phleger and Parker); Ohkushi, Thomas and Kawahata, p. 144 , pl. 3, fig. 2.

Description. Test small, biconvex, trochospiral, circular, and slightly lobulate in outline, with four chambers in the final whorl. Chambers inflated especially in the final whorl, increasing in size rapidly. Sutures clear, incised, straight to slightly curved backwards on the spiral side, straight and radial on the umbilical side. Wall smooth, finely perforated. Aperture basal, with a large flap that covers the entire umbilicus.

Family ORIDORSALIDAE Loeblich and Tappan, 1984

Genus ORIDORSALIS Andersen, 1961

Oridorsalis umbonatus (Reuss, 1851)

Figure 7.2a-c

1851 Rotalina umbonata Reuss: p. 75, pl. 5, fig. 35.

1884 Truncatulina tenera Brady: p. 99, pl. 95, fig. 11.

1982 Oridorsalis umbonatus (Reuss); Matoba and Yamaguchi, p. 1045, pl. 4, fig. 11.

1994 Oridorsalis umbonata (Reuss); Jones, p. 99, pl. 95, fig. 11.

2001 Oridorsalis umbonatus (Reuss); Szarek, p. 144, pl. 24, figs. 1, 2.

2013 Oridorsalis umbonatus (Reuss); Holbourn, Henderson, and MacLeod, p. 384.

Remarks. The specimens in this study possess six to seven chambers in the final whorl.

Family GAVELINELLIDAE Hofker, 1956

Subfamily GAVELINELLINAE Hofker, 1956

Genus Gyroidina d'Orbigny, 1826

Gyroidina? sp. A

Figures $7.3 a-c, 7.4 a-c$

Description. Test small, trochospiral, tightly coiled with a flat spiral side and more convex umbilical 


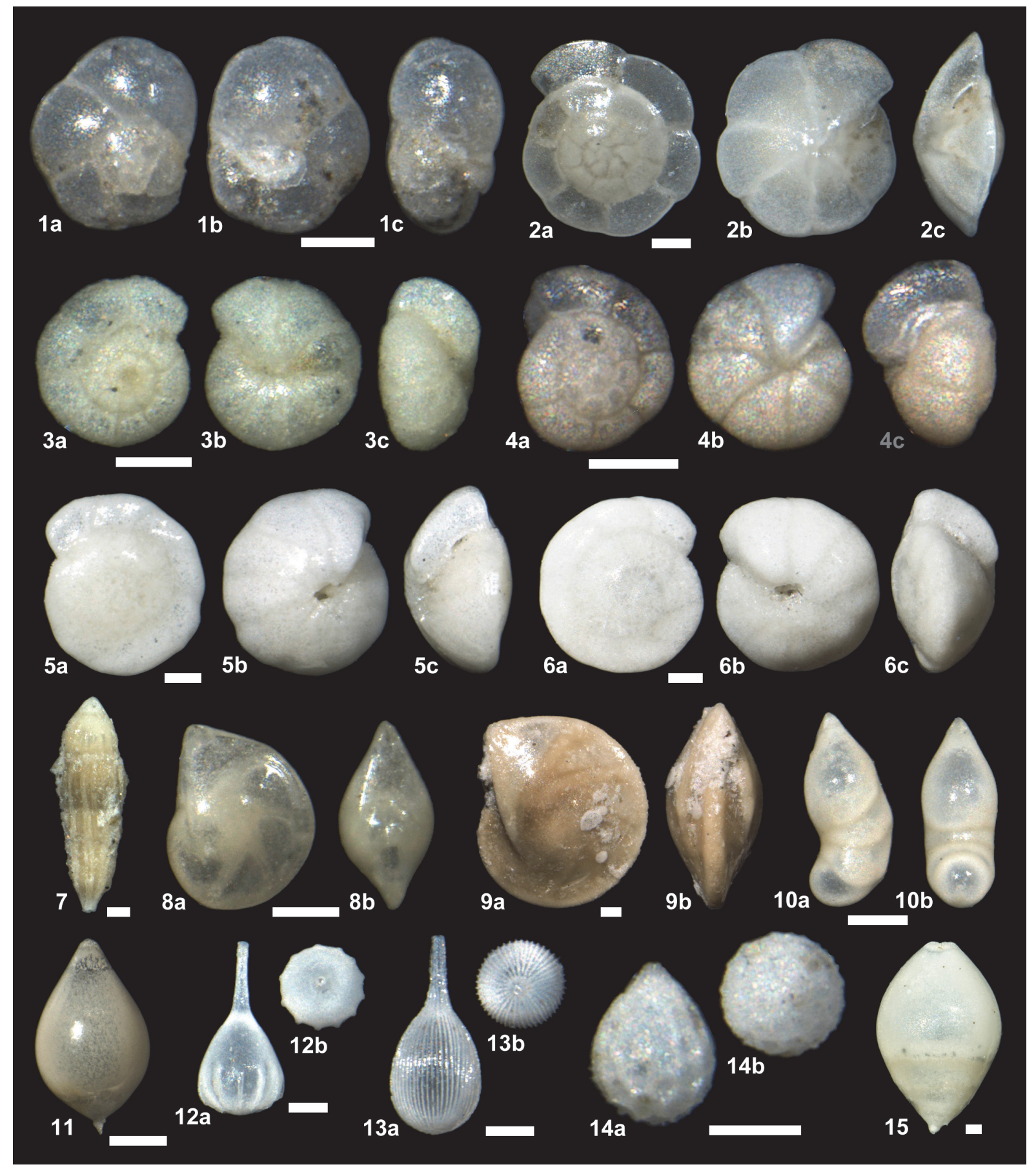

FIGURE 7. All scale bars are $100 \mu \mathrm{m}$. 1. Quadrimorphina laevigata, $13 \mathrm{H}-3,146-148 \mathrm{~cm}$; a. dorsal view; b. ventral view; c. edge view. 2. Oridorsalis umbonatus, 3H-CC; a. dorsal view; b. ventral view; c. edge view. 3. Gyroidina? sp. A, 36H-5, 148-150 cm; a. dorsal view; b. ventral view; c. edge view. 4. Gyroidina? sp. A, 36H-CC; a. dorsal view; b. ventral view; c. edge view. 5. Hansenisca sp. A, 9H-3, 146-148 cm; a. dorsal view; b. ventral view; c. edge view showing a basal slit aperture. 6. Hansenisca sp. A, $16 \mathrm{H}-3,146-148 \mathrm{~cm}$; a. dorsal view; b. ventral view; c. edge view showing a low arch aperture. 7. Epelistoma sp. A, 63X-3, 146-148 cm, lateral view. 8. Lenticulina sp. A, 26H-5, 147$149 \mathrm{~cm}$; a. lateral left view; b. edge view. 9. Lenticulina sp. B, 62X-5, 146-148 cm; a. lateral left view; b. edge view. 10. Hemirobulina sp. A, 9H-5, 146-148 cm; a. lateral left view; b. edge view. 11. Reussoolina apiculata, $28 \mathrm{H}-\mathrm{CC}$, lateral view. 12. Lagena cf. Lagena tagusensis, $12 \mathrm{H}-3,146-148 \mathrm{~cm}$; a. lateral view; b. apertural view. 13. Lagena striata, $10 \mathrm{H}-3,146-148 \mathrm{~cm}$; a. lateral view; b. apertural view. 14. Oolina squamosa, 10H-3, 146-148 cm; a. lateral view; b. apertural view. 15. Glandulina ovula, $36 \mathrm{H}-5,148 / 150 \mathrm{~cm}$, lateral view. 
side, bluntly angled periphery and eight chambers in the final whorl. Umbilicus very small. Chambers increasing in size gradually. Sutures clear, straight, flush, or slightly depressed, radial on the umbilical side. Wall smooth or slightly rough, finely perforated. Aperture a basal slit or a low arch with a lip. It is not clear if there is a bipartitor.

Remarks. This form may be a juvenile of Parrelloides or Hansenisca, which are recorded in this study. The extent of the aperture varies among specimens, but the aperture and the lip do not extend clearly onto the spiral side so that it is not likely that they belong to the genus Cibicidoides. This particular form is found only in two samples.

Genus HANSENISCA Loeblich and Tappan, 1987 Hansenisca sp. A

Figures 7.5a-c, 7.6a-c

Description. Test of medium size, trochospiral, spiral side evolute and flat to slightly elevated, umbilical side involute and elevated, with an small open umbilicus with subangular shoulder, with nine to ten chambers in the final whorl. Periphery more angular than rounded. Chambers increasing in size gradually. Sutures flush or very slightly depressed, curved backwards on the spiral side, radial and straight on the umbilical side. Wall calcareous, very finely perforate, smooth. Aperture an interiomarginal small pore-like opening placed between the umbilicus and the periphery with a narrow lip. A second aperture is present at the umbilicus with a flap.

Remarks. This form resembles species of Gyroidina, such as Gyroidina soldani (d'Orbigny, 1826), but differs by possessing a second aperture at the umbilicus. The size of the umbilicus varies greatly, and it is almost closed in some specimens. A very similar form was reported as Gyroidinoides sp. A from the Izu-Bonin Arc (ODP Legs 125 and 126) by Kaiho (1992, pl. 8, fig. 8).

\section{Hansenisca spp.}

Remarks. Broken specimens with the aperture and the umbilicus that are often not observable. Specimens of Parrelloides might be included.

Family ELPHIDIIDAE Galloway, 1933

Subfamily ELPHIDIINAE Galloway, 1933

Genus ELPHIDIUM de Montfort, 1808

Elphidium batialis Saidova, 1961

Figure 8.21

1961 Elphidium batialis Saidova: p. 77, pl. 23, fig. 161.

1980 Elphidium batialis Saidova; Keller, pl. 4, fig. 4.
1980 Elphidium batialis Saidova; Thompson, pl. 7, figs. 3, 6 .

Remarks. This species is commonly reported from the Pliocene-Recent of the northwest Pacific (e.g., Thompson, 1980; Khusid et al., 2005, 2006; Bubenshchikova et al., 2008). Hanagata (2008) reported it from the Oligocene of southern Hokkaido.

Incertae sedis order

Order LAGENIDA (Delage and Hérouard, 1896)

Superfamily NODOSARIACEA Ehrenberg, 1838

Family CHRYSALOGONIDAE Mikhalevich, 1993

Genus EPELISTOMA Hayward and Kawagata in

Hayward et al. (2012)

Epelistoma sp. A

Figure 7.7

Remarks. Only one specimen is found complete. Differs from Nodosaria lamnulifera Thalmann (1950) by possessing twice as many costae (about 12), which do not extend the full length of the test, and some merge with each other. It also superficially resembles Epelistoma crassitesta (Schwager, 1866), but differs in being smaller and possessing fewer longitudinal costae (about 20-25 in E. crassitesta).

Genus LOTOSTOMOIDES Hayward and

Kawagata in Hayward et al. (2012)

Lotostomoides calomorphum (Reuss, 1866)

Figure 8.22

1866 Nodosaria (Nodosaria) calomorpha Reuss: p. 129 , pl. 1, figs. 15-19.

1884 Nodosaria calomorpha Reuss; Brady, p. 497 , pl. 61, figs. 23-27.

1994 Glandulonodosaria calomorpha (Reuss); Jones, p. 72, pl. 61, figs. 23-26, 27, supplementary plate 1 , figs $10-11$.

2012 Lotostomoides calomorphum (Reuss); Hayward, Kawagata, Sagaa, Grenfell, van Kerckhoven, Johnson and Thomas, p. 125 , pl. 6, figs 24-29.

Remarks. Specimens with only two chambers are recorded in this study. The last chamber is smaller than the penultimate chamber in all the specimens in this study. The somewhat rough wall surface of the specimens in this study may be due to diagenesis.

Family GLANDULONODOSARIIDAE Silvestri, 1901

Genus NEUGEBORINA Popescu in Cicha, Rögl, Rupp, and Ctyroka, 1998

Neugeborina longiscata (d'Orbigny, 1846)

Figure 8.23 


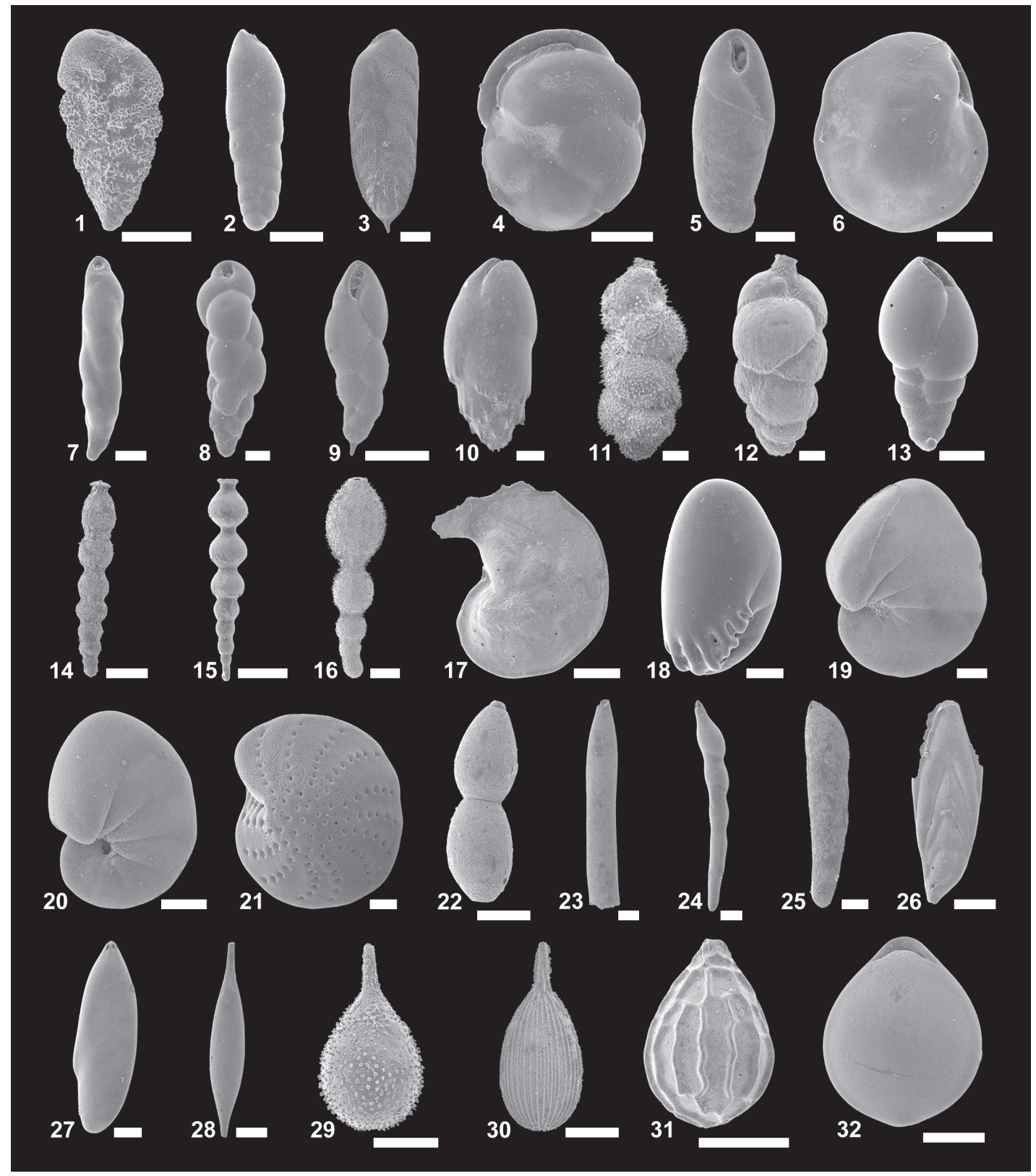

FIGURE 8. All scale bars are $100 \mu \mathrm{m}$. 1. Bolivina sp. A, 1H-CC, lateral view. 2. Brizalina pacifica, 3H-CC, lateral view. 3. Brizalina panayensis, $3 \mathrm{H}-\mathrm{CC}$, lateral view. 4. Takatanagia cf. Takayanagia cushmani, $1 \mathrm{H}-\mathrm{CC}$, lateral view showing the apertural plate. 5. Rutherfordoides tenuis, $16 \mathrm{H}-5,146-148 \mathrm{~cm}$, lateral view. 6. Islandiella helenae, 13H-3, 146$148 \mathrm{~cm}$, lateral view. 7. Eubuliminella exilis, $1 \mathrm{H}-\mathrm{CC}$, lateral view. 8. Eubuliminella cf. Eubuliminella exilis, $3 \mathrm{H}-\mathrm{CC}$, lateral view. 9. Fursenkoina complanata, 3H-CC, lateral view. 10. Globobulimina cf. Globobulimina spinescens, 61X-5, 115-117 cm, lateral view. 11. Uvigerina proboscidea, 59X-3, 145-147 cm, lateral view. 12. Uvigerina senticosa, $8 \mathrm{H}-5$, 146-148 cm, lateral view. 13. Rutherfordoides erectus, $1 \mathrm{H}-\mathrm{CC}$, lateral view. 14. Siphonodosaria? sp. A, 36H-5, 148$150 \mathrm{~cm}$, lateral view. 15. Siphonodosaria? sp. B, 13H-5, 146-148 cm, lateral view. 16. Stilostomella fistuca, $36 \mathrm{H}-\mathrm{CC}$, lateral view. 17. Laticarinina pauperata, $61 \mathrm{X}-\mathrm{CC}$, lateral view. 18. Nonionella digitata, $3 \mathrm{H}-\mathrm{CC}$, lateral view. 19. Nonionellina labradorica, $3 \mathrm{H}-\mathrm{CC}$, lateral view. 20. Nonionellina cf. Nonionellina labradorica, 3H-CC, lateral view. 21. Elphidium batialis, 3H-CC, lateral view. 22. Lotostomoides calomorphum, lateral view. 23. Neugeborina longiscata, 16H-5, 146-148 cm, lateral view. 24. Laevidentalina californica, $26 \mathrm{H}-\mathrm{CC}$, lateral view. 25. Laevidentalina sp. A, 36H-5, 148$150 \mathrm{~cm}$, lateral view. 26. Mucronina sp. A, 61X-CC, lateral view. 27. Astacolus sp., 22H-CC, lateral view. 28. Procerolagena gracillima, $16 \mathrm{H}-5,146-148 \mathrm{~cm}$, lateral view. 29. Lagena hispidula, 13H-5, 146-148 cm, lateral view. 30. Lagena striata, $8 \mathrm{H}-3,146-148 \mathrm{~cm}$, lateral view. 31. Oolina squamosa, $9 \mathrm{H}-5,146-148 \mathrm{~cm}$, lateral view. 32 . Parafissurina caledoniana, $8 \mathrm{H}-\mathrm{CC}$, lateral view. 
1846 Nodosaria longiscata d'Orbigny: p. 32, pl. 1, figs. 10-12.

1998 Neugeborina longiscata (d'Orbigny); Cicha, Rögl, Rupp, and Ctyroka, p. 195, pl. 21, fig. 12.

2009 Neugeborina longiscata (d'Orbigny); Kender, Kaminski, and Jones, p. 515, pl. 19, fig. 6.

2012 Neugeborina longiscata (d'Orbigny); Hayward, Kawagata, Sagaa, Grenfell, van Kerckhoven, Johnson, and Thomas, p. 134, pl. 8, figs. 19-23.

Remarks. All the specimens are broken, and the aperture is not preserved.

Family NODOSARIIDAE Ehrenberg, 1838

Subfamily NODOSARIINAE Ehrenberg, 1838

Genus DENTALINA Risso, 1826

Dentalina spp.

Remarks. Specimens which are elongate, arcuate, and uniserial with a terminal aperture are included. All of them are broken and incomplete, which hinders the species identification.

Genus LAEVIDENTALINA Loeblich and Tappan,
1986
Laevidentalina californica (Cushman and Gray,
1946 )
Figure 8.24

1946 Dentalina californica Cushman and Gray: p. 66 , pl. 12, figs. 3-5.

1994 Dentalina californica (Cushman and Gray); Loeblich and Tappan, p. 64, pl. 115, fig. 4.

Remark. It resembles Laevidentalina aphelis Loeblich and Tappan (1986) in possessing a slender and arcuate test, but differs in its more oblique sutures and large proloculus. It differs from Laevidentalina bradyensis (Dervieux, 1894) by being more slender and possessing a long apertural neck. This form is less robust and much more slender than Laevidentalina sp. A.

\section{Laevidentalina sp. A \\ Figure 8.25}

Description. Test elongated, tapered, arcuate. Chambers increasing gradually in size, not inflated. Sutures slightly oblique, distinct, limbate, only slightly depressed. Wall smooth, without ornamentation. Aperture rounded, terminal on a neck.

Remarks. It differs from Laevidentalina sidebottomi (Cushman, 1933) by its more tapered test with less inflated and more rapidly growing chambers.

Laevidentalina spp.
Remarks. Broken specimens with a uniserial, elongated, and arcuate tests are included.

\section{Genus NODOSARIA Lamarck, 1812 Nodosaria spp.}

Remarks. Broken uniserial specimens with globular chambers are included.

Family PLECTOFRONDICULARIIDAE MontanaroGallitelli, 1957 after Cushman, 1927b

Genus MUCRONINA Ehrenberg, 1839

Mucronina sp. A

Figure 8.26

Description. Test compressed, lanceolate, uniserial throughout, with an acute periphery without a keel. Chambers chevron-shaped, inflated, increasing in size rapidly. Sutures depressed. Wall smooth without ornamentation.

Remarks. The last chambers of all specimens are broken. Specimens may resemble Mucronina spatulata (Costa, 1855), but differ in lacking longitudinal striations.

\section{Mucronina spp.}

Remarks. Broken specimens of various sizes are included. They may also belong to Mucronina sp. A.

Family VAGINULINIDAE Reuss, 1860

Subfamily LENTICULININAE Chapman, Parr and Collins, 1934

Genus LENTICULINA Lamarck, 1804 Lenticulina sp. A Figure 7.8a, b

Description. Test small, circular in outline, planispiral with five to six chambers in the final whorl and an acute periphery. Sutures thick, flush, radial, slightly curved backwards. Chambers increasing in size gradually. Wall smooth without ornamentation. Aperture terminal.

Remarks. It differs from Lenticulina gibba (d'Orbigny, 1839a) by being less elongated in outline and possessing sutures that are only slightly curved backwards and less chambers in the final whorl. It might be a juvenile of Lenticulina sp. B.

\section{Lenticulina sp. B Figure 7.9a, b}

Description. Test large, circular in outline, planispiral with seven and a half chambers in the final whorl and an acute periphery. Sutures thick or slightly elevated, curved backwards. Chambers increasing in size gradually. Wall smooth without ornamentation. Aperture terminal with striations.

\section{Lenticulina spp.}


Remarks. Broken specimens of various sizes and juveniles are included.

Subfamily MARGINULININAE Wedekind, 1937 Astacolus spp.

Figure 8.27

Remarks. Only three specimens were recorded.

Genus HEMIROBULINA Stache, 1864 Hemirobulina sp. A

Figure $7.10 a, b$

Description. Test elongate, with a circular cross section, uniserial, the early part of the test curved, with four chambers. Chambers overlapping, increasing in size gradually, except for the last chamber, which is much larger. Sutures flush, oblique. Wall smooth, without ornamentation. Aperture terminal, on a neck.

\section{Hemirobulina spp.}

Remarks. Specimens of the genus, some of which are broken, are included.

Family LAGENIDAE Reuss, 1862

Genus PROCEROLAGENA Puri, 1953 (1954)

Procerolagena gracillima (Seguenza, 1862)

Figure 8.28

1862 Amphorina gracillima Seguenza: p. 51, pl. 1, fig. 37.

1884 Lagena gracillima (Seguenza); Brady, p. 456, pl. 56, figs. 19-28.

1994 Procerolagena gracillima (Seguenza); Jones, p. 62, pl. 56, figs. 19-22, 24-29.

2012 Hyalinonetrion gracillimum (Costa); Milker and Schmiedl, p. 74, fig. 18.30.

Remarks. The specimens in the studied materials are slender and unornamented. Many of them are broken. This species is retained in Procerolagena following Jones (1994), who considered the genus Hyalinonetrion to be a junior synonym of Procerolagena. The publication date of Puri's original publication is October 10, 1953, but Loeblich and Tappan (1987) reported the publication date as 1954.

Genus REUSSOOLINA Colom, 1956

Reussoolina apiculata (Reuss, 1851)

Figure 7.11

1851 Oolina apiculata Reuss: p. 22, pl. 2, fig. 1.

1993 Reussoolina apiculata (Reuss); Clark and Patterson, fig. 2.7.

Description. Test unilocular, ovate, with an aciculate base. Wall smooth, without ornamentation. Aperture terminal, rounded with radial grooves, on a slight neck.
Family ELLPISOLAGENIDAE Silvestri, 1923

Subfamily OOLININAE Loeblich and Tappan, 1961

Genus LAGENA Walker and Jacob, 1798

Lagena hispidula Cushman, 1913

Figure 8.29

1884 Lagena laevis Montagu; Brady, p. 455, pl. 56, 7-14, 30.

1913 Lagena hispidula Cushman: p. 14, pl. 5, figs. 2, 3.

1994 Lagena hispidula Cushman; Jones, p. 62, pl. 56, figs. 10, 11, 13 .

Remarks. The specimens possess a hispid test, but spines seem to be more robust and less densely distributed than on the specimens illustrated by Cushman (1913) and Jones (1994). The specimens differs from the one illustrated by Milker and Schmiedl (2012, fig. 18.32) by possessing spines and lacking horizontal rings on the apertural neck.

Lagena striata (d'Orbigny, 1839b)

Figures 7.13a, b, 8.30

1839b Oolina striata d'Orbigny: p. 21, pl. 5, fig. 12.

Remarks. This form differs from Lagena sulcata (Walker and Jacob, 1798) by possessing much finer and numerous costae which run from the apertural neck to the bottom of the chamber. The specimens in this study also differ from the one illustrated by Milker and Schmiedl (2012, fig. $18.33)$ by their costae which continue to the apertural neck, and the absence of horizontal rings on the neck.

Lagena cf. Lagena tagusensis McCulloch, 1977

Figure 7.12a, b

1977 Lagena tagusensis McCulloch: p. 48, pl. 50, fig. 10.

Remarks. The specimens differ from the type specimen by lacking the phialine lip on the apertural neck and from Lagena crenata (Parker and Jones, 1865) by possessing a smooth apertural neck without ornamentation and much fewer ridges on the chamber.

\section{Lagena spp.}

Remarks. Different forms of the genus are included.

Genus OOLINA d'Orbigny, 1839b

Oolina squamosa (Montagu, 1803)

Figures 7.14a, b, 8.31

1803 Vermiculum squamosum Montagu: p. 526, pl. 14, fig. 2. 
1884 Lagena squamosa (Montagu); Brady, p. 471, pl. 58, figs. 28-31.

1994 Oolina squamosa (Montagu); Jones, p. 66, pl. 58, figs. 28-32.

Remarks. Specimens with reticulate ornamentation only in the upper half of the test are included in this species. Such a form is illustrated as Oolina cf. Oolina squamosa imperfecta (Buchner) by McCulloch (1977).

\section{Oolina spp.}

Remarks. Different forms some of which are broken and could not be identified at the species level are included.

Subfamily ELLIPSOLAGENINAE Silvestri, 1923 Genus FISSURINA Reuss, 1850

Fissurina spp.

Remarks. Partially broken specimens of the genus are included. A few clearly possess some extended structures.

Subfamily PARAFISSURININAE Jones, 1984

Parafissurina caledoniana McCulloch, 1981 Figure 8.32

1981 Parafissurina caledoniana McCulloch: $p$. 111, pl. 36, figs. 4, 6, 9.

Remarks. Parafissurina sp. B of Kaiho (1992, pl. 2, fig. 19) may also belong to this species.

Family GLANDULINIDAE Reuss, 1860

Subfamily GLANDULININAE Reuss, 1860

Genus GLANDULINA d'Orbigny, 1839a

Glandulina ovula d'Orbigny, 1846

Figure $7.15 a, b$

1846 Glandulina ovula d'Orbigny: p. 29, pl. 1, figs. $6,7$.

1884 Nodosaria (GI.) rotundata Reuss; Brady, p. 491, pl. 61, 17-19.

1994 Glandulina ovula d'Orbigny; Jones, p. 72, pl. 61, figs. 17-22.

Remarks. The specimens from the Bering Sea are not as tapered as the specimen illustrated by d'Orbigny (1846).

\section{Glandulina spp.}

Remarks. Broken specimens that may be assigned to Glandulina ovula, are included here.

\section{ACKNOWLEDGEMENTS}

We thank K. Takahashi for the opportunity to participate in the Expedition 323 scientific party, S. Kender for sampling the core, and R. Balc (BBU), and M. Yahya (KFUPM) for help with sample preparation and SEM images. We are indebted to two anonymous reviewers for helpful comments that improved the manuscript. We are grateful for the support provided by King Abdulaziz City for Science and Technology (KACST) through the Science and Technology Unit at King Fahd University of Petroleum \& Minerals (KFUPM) for partially funding this work under project No. 11-ENV161304 as part of the National Science, Technology, and Innovation Plan.

\section{REFERENCES}

Andersen, H.V. 1961. Genesis and Paleontology of the Mississippi River mudlumps, Part II. Foraminifera of the mudlumps, lower Mississippi River Delta. Louisiana Department of Conservation, Geological Bulletin, 35:1-208.

Anderson, G.J. 1963. Distribution patterns of Recent foraminifera of the Bering Sea. Micropaleontology, 9:305-317.

Asano, K.1950. Part 2, Buliminidae, p. 1-19. In Stach, L.W. (ed.), Illustrated catalogue of Japanese Tertiary smaller foraminifera. Hosokawa Printing Co., Tokyo.

Asano, K. 1951. Part 14, Rotaliidae, p. 1-21. In Stach, L.W. (ed.), Illustrated catalogue of Japanese Tertiary smaller foraminifera. Hosokawa Printing Co., Tokyo.

Asano, K. 1958. The foraminifera from the adjacent seas of Japan, collected by S.S. Soyomaru, 1922-1930, Part 4. Buliminidae. Tohoku University Science Reports, 2nd series (Geology), 28:1-26.

Bailey, J.W. 1851. Microscopical examination of soundings made by the United States Coast Guard Survey off the Atlantic coast of the United States. Smithsonian Contributions to Knowledge, 2, article 3:1-15.

Belanger, P.E. and Berggren, W.A. 1986. Neogene benthic foraminifera of the Hatton-Rockall Basin. Micropaleontology, 32:324-356.

Bernhard, J. 1986. Characteristic assemblages and morphologies of benthic foraminifera from anoxic, organic-rich deposits; Jurassic through Holocene. Journal of Foraminiferal Research, 16:207-215.

Boersma, A. 1984. Handbook of common Tertiary Uvigerina. Microclimate Press, New York.

Boersma, A. 1986. Biostratigraphy and biogeography of Tertiary bathyal benthic foraminifers: Tasman Sea, Coral Sea, and on the Chatham Rise (Deep Sea Drilling Project, Leg 90). In Kennett, J.P. et al. (eds.), Initial Reports of the Deep Sea Drilling Project, 90:961-1035.

Brady, H.B. 1881. Notes on some reticularian Rhizopoda of the Challenger expedition, Part 3. Quaternary Journal of Microscopical Science, 21 (new series):31-71.

Brady, H.B. 1884. Report on the foraminifera dredged by H.M.S. Challenger during the years 1873-1876. In Report on the scientific results of the voyage of H.M.S. Challenger during the years 1873-1876. Zoology, 9:1-814. 
Brady, H.B., Parker, W.K., and Jones, T.R. 1888. On some foraminifera from the Abrolhos Bank. Transactions of the Zoological Society of London, 12(1890):211-239.

Bubenshchikova, N., Nürnberg, D., Lembke-Jene, L., and Pavlova, G. 2008. Living benthic foraminifera of the Okhotsk Sea: Faunal composition, standing stocks and microhabitats. Marine Micropaleontology, 69:314-333.

Butt, A. 1980. Biostratigraphy and paleoenvironmental analyses of the sediments at the Emperor Seamounts, DSDP Leg 55, northwestern Pacific: Cenozoic foraminifers. In Jackson, E.D. et al. (eds.), Initial Reports of the Deep Sea Drilling Project, 55:289325.

Carpenter, W.B., Parker, W.K., and Jones, T.R. 1862. Introduction to the study of the Foraminifera. Ray Society, London.

Caulle, C., Koho, K.A., Mojtahid, M., Reichart, G.J., and Jorissen, F.J. 2014. Live (Rose Bengal stained) foraminiferal faunas from the northern Arabian Sea: faunal succession within and below the OMZ. Biogeosciences, 11:1155-1175.

Chapman, F., Parr, W.J., and Collins, A.C. 1934. Tertiary foraminifera of Victoria, Australia - The Balcombian deposits of Port Phillip, Part III. Journal of the Linnaean Society of London, Zoology, 38:553-577.

Cicha, I., Rögl, F., Rupp, C., and Ctyroka, J. 1998. Oligocene-Miocene foraminifera of the Central Paratethys. Abhandlungen der Senckenbergischen Naturforschenden Gesellschaft, 549:1-325.

Clark, F.E. and Patterson, R.T. 1993. An illustrated key to the identification of unilocular genera of calcareous foraminifera. Journal of Paleontology, 67:20-28.

Cole, F. and Ferguson, C. 1975. An illustrated catalogue of Foraminifera and Ostracoda from Canso Strait and Chedabucto Bay, Nova Scotia. Bedford Institute of Oceanography Report Series, BI-R-75-5:1-55.

Colom, G. 1956. Los foraminíferos del Burdigaliense de Mallorace. Memorias de la Real Academia del Ciencias y Artes de Barcelona, 32:7-140.

Corliss, B.H. 1979. Taxonomy of Recent deep-sea benthonic foraminifera from the southeast Indian Ocean. Micropaleontology, 25:1-19.

Corliss, B.H. 1985. Microhabitats of benthic foraminifera within deep-sea sediments. Nature, 314:435-438.

Corliss, B.H. 1991. Morphology and microhabitat preferences of benthic foraminifera from the northwest Atlantic Ocean. Marine Micropaleontology, 17:195236.

Costa, O.G. 1855. Foraminiferi fossili delle marne Terziarie di Messina. Memoire della Reale Accademia Scienza Napoli, 2:128-147, 367-373.

Costa, O.G. 1856. Paleontologia del regno di Napoli, Parte II. Atti dell 'Accademia Pontaniana Napoli, 7:113-378.

Cushman, J.A. 1911. A monograph of the foraminifera of the North Pacific Ocean, part 2. Textulariidae. United States National Museum Bulletin, 71:1-108.
Cushman, J.A. 1913. A monograph of the foraminifera of the North Pacific Ocean. Pt. III - Lagenidae. U.S. National Museum Bulletin, 71(3):1-125.

Cushman, J.A. 1922. The foraminifera of the Atlantic Ocean, Part 3: Textularidae. Bulletin of the United States National Museum, 104(3):1-143.

Cushman, J.A. 1923. The foraminifera of the Atlantic Ocean; Part 4 - Lagenidae. U.S. National Museum Bulletin, 104(4):1-228.

Cushman, J.A. 1926a. Foraminifera of the typical Monterey of California. Contributions from the Cushman Laboratory for Foraminiferal Research, 2:53-69.

Cushman, J.A. 1926b. The genus Chilostomella and related genera. Contributions from the Cushman Laboratory Research, 1:73-80.

Cushman, J.A. 1927a. Recent foraminifera from off the west coast of America. Bulletin of the Scripps Institute of Oceanography, technical series, 1:119-188.

Cushman, J.A. 1927b. An outline of a re-classification of the foraminifera. Contributions from the Cushman Laboratory for Foraminiferal Research, 3:1-105.

Cushman, J.A. 1928. Foraminifera. Their Classification and Economic Use. Cushman Laboratory for Foraminiferal Research, Special Publication, 1:1-401.

Cushman, J.A. 1933. New Arctic foraminifera collected by Capt. R.A. Bartlett from Fox Basin and off the northeast coast of Greenland. Smithsonian Miscellaneous Collections, 89:1-8.

Cushman, J.A. 1935. Fourteen new species of foraminifera. Smithsonian Miscellaneous Collections, 91(21):1-9.

Cushman, J.A. and Edwards, P.G. 1937. Astrononion, a new genus of the foraminifera, and its species. Contributions from the Cushman Laboratory for Foraminiferal Research, 13:29-36.

Cushman, J.A. and Gray, H.B. 1946. Some new species and varieties of foraminifera from the Pliocene of Timms Point, California. Contributions from Cushman Laboratory for Foraminiferal Research, 22:6569.

Cushman, J.A. and McCulloch, I., 1942. Some Virgulininae in the collections of the Allan Hancock Foundation. Allan Hancock Pacific Expedition, 6:179-230.

Cushman, J.A. and Moyer, D.A. 1930. Some recent foraminifera from off San Pedro, California. Contributions from the Cushman Laboratory for Foraminiferal Research, 6:49-62.

Cushman, J.A. and Renz, H.H. 1941. New OligoceneMiocene foraminifera from Venezuela. Contributions from Cushman Laboratory of Foraminiferal Research, 17:1-27.

Cushman, J.A. and Todd, R. 1943. The genus Pullenia and its species. Contributions from Cushman Laboratory for Foraminiferal Research, 19:1-23.

Cžjzek, J. 1849. Über zwei neue Arten von Foraminiferen aus dem Tegel von Baden und Möllersdorf. Bericht über die Mittheilungen Freunden der Naturwissenschaften in Wien, 5:50-56. 
Dawson, J.W. 1860. Notice of Teartiary fossils fro Labrador, Maine, etc., and remarks on the climate of Canada in the newer Pliocene or Pleistocene period. Canadian Naturalist, 5:188-200.

Defrance, J.L.M. 1824. Dictionnnaire des Science Naturelles 32. F.G. Levrault, Strasbourg.

Delage, Y. and Hérouard, E. 1896. Traité de zoologie concrète. Tome I: La cellule et les Protozoaires. Schleicher Frères, Paris.

de Montfort, D. 1808. Conchyliologie Systématique et Classification Méthodique des Coquilles, Volume 1, F. Schoell, Paris.

Dervieux, E. 1894. Le Nodosarie terziarie del Piemonte. Bolletino della Societá Geologica Italiana, Roma, 12 (1893):591-626.

d'Orbigny, A. 1826. Tableau methodique de la classe des Céphalopodes. Annales des Sciences Naturelles, 7:245-314.

d'Orbigny, A. 1839a. Foraminiféres, 224 p. In De la Sagra, R.M. (ed.), Histoire physique, politique et naturelle de L'ile de Cuba. Arthus Bertrand, Paris.

d'Orbigny, A. 1839b. Voyage dans I'Amérique Méridonale - Foraminiferes, 5. Imprimerie de veuve BergerLevrault, Strasburg.

d'Orbigny, A. 1846. Die fossilen Foraminiferen des tertiären Beckens von Wien. Gide et Comp, Paris.

Eade, J.V. 1967. New Zealand recent Foraminifera of the families Islandiellidae and Cassidulinidae. New Zealand Journal of Marine and Freshwater Research, 1:421-454.

Earland, A. 1936. Foraminifera; Part IV - Additional records from the Weddell Sea sector from material obtained by the S.Y. Scotia. Discovery Report, 13:176.

Echols R.J. 1973. Foraminifera, Leg 19, Deep Sea Drilling Project. In Creager, J.S. et al. (eds.), Initial Reports of the Deep Sea Drilling Project, 19:721735.

Egger, J.G. 1893. Foraminiferen aus Meeresgrundproben, gelothet von 1874 bis 1876 von S.M. Sch. Gazelle. Abhandlungen der Bayrischen Akademie der Wissenschaften, Mathematisch-Physikalische Classe, 18:193-458.

Ehrenberg, C.G. 1838. Über dem blossen Auge unsichtbare Kalkthierchen und Kieselthierchen als Hauptbestandtheile der Kreidegebirge. Bericht über die zur Bekanntmachung geeigneten Verhandlungen der Königlichen Preussischen Akademie der Wissenschaften zu Berlin, 1838, 3:192-200.

Ehrenberg, C.G. 1839. Über die Bildung der Kreidefelsen und des Kreidemergels durch unsichtbare Organismen. Abhandlungen der Königlichen Akademie der Wissenschaften zu Berlin, 1838:59-147.

Expedition 323 Scientists. Expedition 323 summary. Proceedings of the Integrated Ocean Drilling Program, 323:1-53.

Fariduddin, M. and Loubere, P. 1997. The surface ocean productivity response of deeper water benthic fora- minifera in the Atlantic Ocean. Marine Micropaleontology, 32:289-310.

Feyling-Hanssen, R. and Buzas, M.A. 1976. Emendation of Cassidulina and Islandiella helenae new species. Journal of Foraminiferal Research, 6:154-158.

Fichtel, L. and Moll, J.P.C. 1798. Testacea microscopica aliaque minuta ex generibus Argonauta et Nautilus ad naturam delineata et descripta. A. Pichler, Vienna.

Finger, K.L. 1990. Atlas of California Neogene foraminifera. Cushman Foundation for Foraminiferal Research, 28.

Finger, K.L. 1992. Biostratigraphic atlas of Miocene foraminifera from the Monterey and Modelo formations, central and southern California. Cushman Foundation for Foraminiferal Research, Special Publication, 29.

Finger, K.L. and Lipps, J.H. 1981. Foraminiferal decimation and repopulation in an active volcanic caldera, Deception Island, Antarctica. Micropaleontology, 27:111-139.

Finlay, H.J. 1939. New Zealand foraminifera, key species in stratigraphy. Royal Society of New Zealand, Transaction, 68:504-543.

Finlay, H.J. 1947. New Zealand Foraminifera: Key species in stratigraphy-No. 5. New Zealand Journal of Science and Technology, 28:259-292.

Galloway, J.J. 1933. A Manual of Foraminifera. Principal Press, Bloomington.

Galloway, J.J. and Wissler, S.G. 1927. Correction of names of foraminifera. Journal of Paleontology, $1: 193$.

Glaessner, M.F. 1937. Die Entfaltung der Foraminiferen familie Buliminidae. Problemy Paleontologii, Paleontologicheskaya Laboratoriya Moskovskogo Gosudarstvennogo Universiteta, 2-3:411-422.

Gudina, V.L. 1966. Foraminifera and stratigraphy of the northwest Siberian Quaternary. Akademii Nauk SSSR Siberian Department, Institute of Geology and Geophysics, 26.

Guppy, R.J.L. 1894. On some foraminifera from the Microzoic deposits of Trinidad, West Indies. Proceedings of the Zoological Society of London, 1894:647652.

Haeckel, E. 1894. Systematische Phylogenie. Entwurf eines Natürlichen Systems der Organismen auf Grund ihrer Stammesgeschichte, Theil 1, Systematische Phylogenie der Protisten und Pflanzen. Georg Reimer, Berlin.

Hanagata, S. 2008. Oligocene shallow marine foraminifera from the subsurface of southern Hokkaido. Paleontological Research, 12:99-118.

Hayward, B.W. 2002. Late Pliocene to middle Pleistocene extinctions of deep-sea benthic foraminifera ("Stilostomella extinction") in the southwest Pacific. Journal of Foraminiferal Research, 32:274-307.

Hayward, B.W., Kawagata, S., Sabaa, A., Grenfell, H., van Kerckhoven, L., Johnson, K., and Thomas, E. 2012. The last global extinction (Mid-Pleistocene) of deep-water benthic foraminifera (Chrysalogoniidae, 
Ellipsoidinidae, Glandulonodosariidae, Plectofrondiculariidae, Pleurostomellidae, Stilostomellidae), their Late Cretaceous-Cenozoic history and taxonomy. Cushman Foundation for Foraminiferal Research, Special Publication, 43.

Hermelin, J.O.R. 1989. Pliocene benthic foraminifera from the Ontong-Java Plateau (western equatorial Pacific Ocean): Faunal response to changing paleoenvironment. Cushman Foundation for Foraminiferal Research, 26.

Hofker, J. 1951. The foraminifera of the Siboga Expedition. Part III. Siboga Expeditie, Monographie IVb. E.J. Brill, Leiden.

Hofker, J. 1956. Tertiary foraminifera of coastal Ecuador: Part II, Additional notes on Eocene species. Journal of Paleontology, 30:891-958.

Holbourn, A., Henderson, A.S., and MacLeod, N. 2013. Atlas of Benthic Foraminifera. Wiley-Blackwell, Oxford.

Hoskin, I.R. and Haskins, C.W. 1975. Occurrence of Late Miocene Chilostomellina fimbriata Cushman in the North Sea. Micropaleontology, 21:243-245.

Husezima, R. and Maruhasi, M. 1944. A new genus and thirteen new species of foraminifera from the coresample of Kasiwazaki oil-field, Niigata-ken. Shigenkagaku Kenkyusyo, Journal, 1:391-400.

Ishimura, T., Tsunogai, U., Hasegawa, S., Nakagawa, F., Oi, T., Kitazato, H., Suga, H., and Toyofuku, T. 2012. Variation in stable carbon and oxygen isotopes of individual benthic foraminifera: tracers for quantifying the magnitude of isotopic disequilibrium. Biogeosciences, 9:4353-4367.

Jones, T.R. 1875. Foraminifera, pp. 316-320. In Griffith, J.W. and Henfrey, A. (eds.), The Micrographic Dictionary, Van Voorst, London.

Jones, R.W. 1984. A revised classification of the unilocular Nodosariida and Buliminida (Foraminifera). Revista Española de Micropaleontologia, 16:91-160.

Jones, R.W. 1994. The Challenger Foraminifera. Oxford University Press, Inc., New York.

Kaiho, K. 1992. Eocene to Quaternary benthic foraminifers and paleobathymetry of the Izu-Bonin Arc, Legs 125 and 126. In Taylor, B., et al. (eds.), Proceedings of the Ocean Drilling Program, Scientific Results, 126:285-310.

Kaminski, M.A., Kender, S., Ciurej, A., Balc, R., and Setoyama, E. 2013. Pliocene agglutinated benthic foraminifera from Site U1341 in the Bering Sea (IODP Expedition 323). Geological Quarterly, 57:335-342.

Kato, M. 1992. Benthic foraminifers from the Japan Sea: Leg 128. In Pisciotto, K.A. et al. (eds.), Proceedings of the Ocean Drilling Program, Scientific Results, 127/128:365-392.

Keller, G. 1980. Benthic foraminifers and paleobathymetry of the Japan Trench area, Leg 57, Deep Sea Drilling Project. In von Huene, R. et al. (eds.), Initial Reports of the Deep Sea Drilling Project, 56/57:835865
Kender, S., Kaminski, M.A., and Jones, R.W. 2009. Early to middle Miocene foraminifera from the deep-sea Congo Fan, offshore Angola. Micropaleontology, 54:477-568.

Khusid, T.A., Barash, M.S., Biebow, N., Nuernberg, D., and Tiedemann, R. 2005. Late Quaternary environmental changes of the southeastern slope of the Sea of Okhotsk inferred from benthic foraminifera. Oceanology, 45:413-419.

Khusid, T.A., Basov, I.A., Gorbarenko, S.A., and Chekhovskaya, M.P. 2006. Benthic foraminifers in Upper Quaternary sediments of the southern Bering Sea: Distribution and paleoceanographic interpretations. Stratigraphy and Geological Correlation, 14:538548.

Kohl, B. 1985. Early Pliocene benthic foraminifers from the Salina Basin, southeastern Mexico. Bulletins of American Paleontology, 88(322):1-173.

Koho, K.A., Gracía, R., de Stigter, H.C., Epping, E., Koning, E., Kouwenhoven, T.J., and Van der Zwaan, G.J. 2008. Sedimentary labile organic carbon and pore water redox control on species distribution of benthic foraminifera: A case study from Lisbon-Setúbal Canyon (southern Portugal). Progress in Oceanography, 79:55-82.

Lamarck, J.B. 1804. Suite des mémoires sur les fossils des environs de Paris. Annales Muséum National d'Histoire Naturelle, 5:179-188.

Lamarck, J.B. 1812. Extrait du cours de zoologie du Muséum d'histoire naturelle sur les animaux sans vertèbres. d'Hautel and Gabon, Paris.

Lankford, R.R. and Phleger, F.B. 1973. Foraminifera from the nearshore turbulent zone, western North America. Journal of Foraminiferal Research, 3:101132.

LeRoy, L.W. 1944. Miocene foraminifera from Sumatra and Java, Netherlands East Indies. Colorado School of Mines Quarterly, 39(3):113 p.

Loeblich, A.R., Jr. and Tappan, H. 1953. Studies of Arctic Foraminifera. Smithsonian Miscellaneous Collections, 121(7):1-151.

Loeblich, A.R., Jr. and Tappan, H. 1955. Revision of some Recent foraminiferal genera. Smithsonian Miscellaneous Collections, 128:1-37.

Loeblich, A.R., Jr. and Tappan, H. 1961. Supragenetic classification of the Rhizopodea. Journal of Paleontology, 35:245-330.

Loeblich, A.R., Jr. and Tappan, H. 1984. Suprageneric classification of the Foraminiferida (Protozoa). Micropaleontology, 30:1-70.

Loeblich, A.R., Jr. and Tappan, H. 1986. Some new and revised genera and families of hyaline calcareous foraminiferida (Protozoa). Transactions of the American Microscopical Society, 105:239-265.

Loeblich, A.R., Jr. and Tappan, H. 1987. Foraminiferal Genera and Their Classification. Van Nostrand Reinhold Company, New York.

Loeblich, A.R., Jr. and Tappan, H. 1994. Foraminifera of the Sahul Shelf and Timor Sea. Cushman Founda- 
tion for Foraminiferal Research, Special Publication, 31.

Lutze, G.F. 1986. Uvigerina species of the eastern North Atlantic. Utrecht Micropaleontological Bulletins, 35:21-46.

Matoba, Y. 1967. Younger Cenozoic foraminiferal assemblages from the Choshi district, Chiba prefecture. The scientific reports of the Tohoku University, 2nd series, Geology, 38:221-263.

Matoba, Y. and Yamaguchi, A. 1982. Late Pliocene to Holocene benthic foraminifers of the Guaymas Basin, Gulf of California: Sites 477 through 481. Initial Reports of the Deep Sea Drilling Project, 64:1027-1056.

Matsunaga, T. 1963. Benthonic smaller foraminifera from the oil field of northern Japan. The scientific reports of the Tohoku University, 2nd series, Geology, 35:65122

McCulloch, I. 1977. Qualitative observations on Recent foraminiferal tests with emphasis on the Eastern Pacific, parts I-III. University of Southern California, Los Angeles.

McCulloch, I. 1981. Qualitative observations on Recent foraminiferal test with emphasis on the Allan Hancock Atlantic Expedition Collection, part IV. University of Southern California, Los Angeles.

Mikhalevich, V.I. 1993. New higher taxa of the Subclass Nodosariata (Foraminifera). Zoosystematica Rossica, 2:5-8.

Milker, Y. and Schmiedl, G. 2012. A taxonomic guide to modern benthic shelf foraminifera of the western Mediterranean Sea. Palaeontologia Electronica, 15(2):16A:134p. palaeo-electronica.org/content/ 2012-issue-2-articles/223-taxonomy-foraminifera

Montagu, G. 1803. Testacea Britannica or Natural History of British shells, marine, land, and fresh-water, including the most munute: systematically arranged and embellished with figures. Romsey, London.

Montanaro-Gallitelli, E. 1957. A revision of the foraminiferal family Heterohelicidae. United States National Museum, Bulletin, 215:133-154.

Nomura, R. 1983a. Cassidulinidae (Foraminiferida) from the uppermost Cenozoic of Japan (Part 1). Tohoku University Science Reports, 2nd series (Geology), 53:1-101.

Nomura, R. 1983b. Cassidulinidae (Foraminiferida) from the Uppermost Cenozoic of Japan (Part 2). Tohoku University Science Reports, 2nd series (Geology), 54:1-93

Nomura, R. 1999. Miocene cassidulinid foraminifera from Japan. Palaeontological Society of Japan Special Publication, 38:1-69.

Norris, R.D. 1992. Umbilical structures in Late Cretaceous planktonic foraminifera. Micropaleontology, 38:165-181.

Nørvang, A. 1945. Foraminifera. Zoology of Iceland, 2(2):1-79.
Nørvang, A. 1959. Islandiella n.g. and Cassidulina d'Orbigny. Videnskabelige Meddeleser fra Dansk Naturhistorisk Forening i Kjøbenhavn, 120:25-41.

Ohkushi, K., Thomas, E., and Kawahata, H. 2000. Abyssal benthic foraminifera from the northwestern Pacific (Shatsky Rise) during the last 298 kyr. Marine Micropaleontology, 38:119-147.

Onodera, J., Takahashi, K., and Nagatomo, R. 2013. Diatoms, silicoflagellates, and ebridians at Site U1341 on the western slope of Bowers Ridge, IODP Expedition 323. Deep-Sea Research II, dx.doi.org/ 10.1016/j.dsr2.2013.03.025i

Ortiz, S. and Thomas, E. 2006. Lower-middle Eocene benthic foraminifera from the Fortuna Section (Betic Cordillera, southeastern Spain). Micropaleontology, 52:97-150.

Parker, F.L. 1954. Distribution of the foraminifera in the northeastern Gulf of Mexico. Bulletin of The Museum of Comparative Zoology, 111:451-588.

Parker, W.K. and Jones, T.R. 1865. On some foraminifera from the North Atlantic and Arctic Oceans, including Davis Strait and Baffin's Bay. Philosophical Transactions of the Royal Society of London, 155:325-441.

Parr, W.J. 1950. Foraminifera. Reports B.A.N.Z. Antarctic Research Expedition 1929-1931, Series B, 5:232-392.

Pawlowski, J., Holzmann, M., and Tyszka, J. 2013. New supraordinal classification of Foraminifera: Molecules meet morphology. Marine Micropaleontology, 100:110.

Pflum, C.E. and Frerichs, W.E. 1976. Gulf of Mexico deep-water foraminifers. Cushman Foundation for Foraminiferal Research, Special Publication, 14.

Phleger, F.B. and Parker, F.L. 1951. Ecology of foraminifera, northwest Gulf of Mexico, Part II, Foraminifera species. Geological Society of America Memoir, 46:1-59.

Piveteau, J. 1952. Traité de Paléontologie, volume 1. Masson et Cie, Paris.

Puri, H.S. 1953 (1954). Contribution to the study of the Miocene of the Florida Panhandle Part II-Foraminifera. Florida Geological Survey Geological Bulletin, 36:5-213.

Reiss, Z. 1963. Reclassification of perforate foraminifera. Bulletin of the Geological Survey of Israel, 35:1-111.

Reuss, A.E. 1850. Neue Foraminiferen aus den Schichten des österreichischen Tertiärbeckens. Denkschriften der mathematisch-naturwissenschaftlichen Classe der kaiserlichen Akademie der Wissenschaften (1849), 1:360-395.

Reuss, A.E. 1851. Ueber die fossilen Foraminiferen und Entomostraceen der Septarienthone der Umgegend von Berlin. Zeitschrift der Deutschen Geologischen Gesellschaft, Berlin, 3:49-91.

Reuss, A.E. 1860. Die Foraminiferen der Westphälischen Kreideformation. Sitzungsberichte der Kaiserlichen Akademie der Wissenschaften in Wien, 
Mathematisch-Naturwissenschaftliche Classe, 40:147-238.

Reuss, A.E. 1862. Entwurf einer systematischen Zusammenstellung der Foraminiferen. Sitzungsberichte der Kaiserlichen Akademie der Wissenschaften in Wien, Mathematisch-Naturwissenschaftliche Classe (1861), 44:355-396.

Reuss, A.E. 1866. Die foraminiferen, Anthozoen und Bryozoen des deutschen Septarienthones. Kaiserlichen Akademie der Wissenschaften in Wien, Mathematisch-Naturwissenschaftliche Klasse, 25:117-214.

Revets, S.A. 1989. Structure and comparative anatomy of the tooth plate in the Buliminacea (Foraminiferida). Journal of Micropalaeontology, 8:23-36.

Revets, S.A. 1993. The revision of the genus Buliminellita Cushman and Stainforth, 1947, and Eubuliminella gen. nov. Journal of Foraminiferal Research, 23(2):141-151.

Revets, S.A. 1996. The generic revision of five families of roaliine foraminifera. Part I The Bolivinitidae Cushman, 1927. Cushman Foundation for Foraminiferal Research, Special Publication, 34:1-55.

Risso, A. 1826. Histoire naturelle des principales productions de l'Europe Mériodinale et particulièrment de celles des environs de Nice et des Alpes maritimes, 4. F.G. Levrault, Paris.

Rodrigues, C.G., Hooper, K., and Jones, P.C. 1980. The apertural structures of Islandiella and Cassidulina. Journal of Foraminiferal Research, 10:48-60.

Saidova, K.M. 1961. Ekologiya foraminifer I paleogeographiya dalnevostochnih morei SSSR $i$ severozapadnoi chasti Tihogo okeana. Akademiya Nauk SSR, Moscow. (In Russian)

Saidova, K.M. 1975. Bentosnye Foraminifery Tikhogo Okeana. Institut Okeanologii P.P. Shirshova, Akademiya Nauk SSR, Moscow. (In Russian)

Saidova, K.M. 1981. O sovremennom sostoyanii sistemy nadvidovykhtaksonov Kaynozoyskikh foraminifer. Institut Okeanologii P. P. Shirshova, Akademiya Nauk SSSR, Moscow. (In Russian)

Schwager, C. 1866. Fossile Foraminiferen von Kar Nicobar: Novara Expeditions. Geologischer Theil, 2:187268.

Schwager, C. 1876. Saggio du una classificazione dei foraminiferi avuto riguardo alle lore famiglie naturali. Bolletino R. Comitato Geologico d'Italia, 7:475-485.

Schwager, C. 1877. Quadro del proposto sistema di classificazione dei foraminiferi con guscio. Bolletino R. Comitato Geologico d'Italia, 8:18-27.

Schwager, C. 1878. Nota su alcuni Foraminiferi nuovi del Tubo di Stretto presso Girgenti. Bolletino R. Comitato Geologico d'Italia, 9:519-529.

Schultze, M.S. 1854. Über den Organismus der Polythalamien (Foraminiferen) nebst Bemerkungen über die Rhizopoden im Allgemeinen. Engelmann, W., Leipzig.

Schweizer, M., Pawlowski, J., Duijnstee, I.A.P., Kouwenhoven, T.J., and Van der Zwaan, G.J. 2005. Molecular phylogeny of the foraminiferal genus Uvigerina based on ribosomal DNA sequences. Marine Micropaleontology, 57:51-67.

Schweizer, M. 2006. Evolution and molecular phylogeny of Cibicides and Uvigerina (Rotaliida, Foraminifera). Geologica Ultraiectina, 261.

Schweizer, M., Pawlowski, J., Kouwenhoven, T., and Van der Zwaan, B. 2009. Molecular phylogeny of common cibicidids and related Rotaliida (Foraminifera) based on small subunit rDNA sequences. Journal of Foraminiferal Research, 39:300-315.

Schweizer, M., Fontaine, D., and Pawlowski, J. 2011. Phylogenetic position of two Patagonian Cibicididae (Rotaliida, Foraminifera): Cibicidoides dispars (d'Orbigny, 1839) and Cibicidoides variabilis (d'Orbigny, 1826). Revue de micropaléontologie, 54:175-182.

Scott, D.B., Takayanagi, Y., Hasegawa, S., and Saito, T. 2000. Illustration and taxonomic reevaluation of Neogene foraminifera described from Japan. Palaeontologia Electronica, 3:41p; palaeo-electronica.org/ 2000_2/foram/issue2_00.htm

Seguenza, G. 1862. Dei terreni Terziarii del distretto di Messina, Parte II, Descrizione dei foraminiferi monothalamici delle marne Mioceniche del distretto di Messina. Capra, T., Messina.

Sigal, J. 1952. Aperçu stratigraphique sur la micropaléontologie du crétacé. XIX Congrés Géologique International, Monographies Régionales, série I, Algérie, 26:1-47.

Silvestri, A. 1901. Intorno ad alcune Nodosarine poco conosciute del neogene italiano. Atti Accademia Pontifcia dei Nuovi Lincei, 54:103-109.

Silvestri, A. 1923. Lo stipite della Elissoforme e le sue affinitá. Memorie della Pontificia Accademia della Scienze, Nuovi Lincei, Series 2:231-270.

Silvestri, A. 1924. Fauna paleontologia di Casciano presso Todi. Bollettino della Societa Geologica Italiana, 42:7-29.

Sliter, W.V. 1970. Inner-neritic Bolivinitidae from the eastern Pacific margin. Micropaleontology, 16:155-174.

Stache, G. 1864. Die Foraminiferen der tertiären Mergel des Whaingaroa-Hafens (Provinz Auckland). Novara-Expedition, 1857-1859, Vol. 1, Geologische Theil No. 2:159-304.

Stewart, R.E. and Stewart, K.C. 1930. Post-Miocene foraminifera from the Ventura Quandrangle, Ventura County, California: Twelve new species of varieties from the Pliocene. Journal of Paleontology, 4:60-72.

Szarek, R. 2001. Biodiversity and biogeography of recent benthic foraminiferal assemblages in the south-western South China Sea (Sunda Shelf). Unpublished PhD Thesis, Christian-Albrechts-Universität zu Kiel, Kiel, Germany.

Tappan, H. 1951. Northern Atlantic index foraminifera. Contributions from the Cushman Foundation for Foraminiferal Research, 2:1-8.

Takahashi, K., Ravelo, C., Zarikian, C.A., and the IODP Expedition 323 Scientists. 2011. IODP ExpeditionPliocene and Pleistocene paleoceanographic 
changes in the Bering Sea. Scientific Drilling, 11:413.

Thalmann, H.E. 1950. New names and homonyms in foraminifera. Contributions from the Cushman Foundation for Foraminiferal Research, 1:41-45.

Thompson, P.R. 1980. Foraminifers from Deep Sea Drilling Project Sites 434, 435, and 436, Japan Trench. In von Huene, R. et al. (eds.), Initial Reports of the Deep-Sea Drilling Project, 56/57:775-807.

Uchio, T. 1960. Ecology of living benthonic foraminifera from the San Diego, California, Area. Cushman foundation for foraminiferal research, Special publication, 5.

Van der Zwaan, G.J., Jorissen, F.J., Verhallen, P.J.J.M., and von Daniels, C.H., 1986. Uvigerina from the eastern Atlantic, North Sea Basin, Paratethys and Mediterranean. Utrecht Micropaleontological Bulletins, 36:7-20.

van Morkhoven, F.P.C.M., Berggren, W.A., and Edwards, A.S. 1986. Cenozoic cosmopolitan deep-water benthic foraminifera. Bulletin des Centres Recherches Exploration-Production Elf-Aquitaine, Memoir, 11:1423.

Vázquez Riveiros, N. and Patterson, T.R. 2007. An Illustrated Guide to Fjord Foraminifera from the Seymourbelize Inlet Complex, Northern British Columbia, Canada. Palaeontologia Electronica, 11(1): 2A:45p. palaeo-electronica.org/2008_1/145/index.html
Vella, P. 1957. Studies in New Zealand foraminifera. Paleontological Bulletin, Wellington, 28:1-64.

Voloshinova, N.A. 1958. O novy sistematike Nonionid (On new systematics of the Nonionidae). Trudy vsesoyuznogo neftyanogo nauchnoissledovatel'skogo geologorazvedochnogo instituta (VNIGRI), 115:117191. (In Russian)

Voloshinova, N.A. 1960. Uspekhi mikropaleontologii v dele izucheniya vnutrennego stroeniya foraminifer, $\mathrm{p}$. 48-87. In Subbotina, N.N. (ed.), Trudy Pervogo Seminara po Mikrofaune. Vsesoyuznyy Neftyanoy Nauchno-issledovatel'skii Geologorazvedochnyy Institut (VNIGRI), Leningrad. (In Russian)

Voloshinova, N.A. and Dain, L.G. 1952. Iskopaemye Foraminifery SSSR. Nonionidy, Kassidulinidy i Khilostomellidy. Trudy Vsesoyuznogo Neftyanogo Nauchnoissledovatel'skogo Geologor-razvedochnogo Instituta (VNIGRI), 63:1-151. (In Russian)

Walker, G. and Jacob, E. 1798. In Kanmacher, F. (ed.), Adam's Essay on the Microscope. Dillon and Keating, London.

Wedekind, P.R. 1937. Einführung in die Grundlagen der historischen Geologie, Band II, Mikrobiostratigraphie der Korallen- und Foraminiferenzeit. Ferdinand Enke, Stuttgart.

Williamson, W.C. 1858. On the Recent foraminifera of Great Britain. Ray Society, London.

\section{APPENDIX}

Counts of specimens. File in electronic format at: palaeo-electronica.org/content/2015/1264-bering-benthic-forams 